\title{
Serotonergic modulation of suicidal behaviour: integrating preclinical data with clinical practice and psychotherapy
}

\author{
Vasileios Boulougouris • Ioannis Malogiannis • \\ George Lockwood · Iannis Zervas • \\ Giuseppe Di Giovanni
}

Received: 6 May 2013 / Accepted: 30 July 2013

(C) Springer-Verlag Berlin Heidelberg 2013

\begin{abstract}
Many studies have provided important information regarding the anatomy, development and functional organization of the 5-HT system and the alterations in this system that are present within the brain of the suicidal patient. There is also a growing interest in genetic factors associated with suicide, since these may lead to the emergence of personality traits that prove to be longterm predictors of suicidal behaviour. This review will focus on presenting the scientific literature on the role of the serotonergic system in suicidal behaviour as well as dysfunctional attitudes and personality traits associated with the suicidal patient. The association of the serotonin transporter gene, the 5-HT2 receptors and its metabolite 5-hydroxyindoleacetic acid with suicidal behaviour and animal models that may capture the complexity of suicidal behaviour will be discussed. Finally, the relationship between neurobiological models and psychotherapeutic interventions for suicide prevention will be considered with a focus on Schema Therapy (an approach that has shown particular promise in the treatment of suicidal individuals
\end{abstract}

V. Boulougouris $(\varangle) \cdot$ I. Malogiannis $\cdot$ I. Zervas

Greek Society of Schema Therapy, Athens, Greece

e-mail: vboulougouris@googlemail.com

V. Boulougouris $\cdot$ I. Malogiannis $\cdot$ I. Zervas

1st Department of Psychiatry, Eginition Hospital,

Athens Medical School, Athens, Greece

G. Lockwood

Schema Therapy Institute Midwest, Kalamazoo, MI, USA

G. Di Giovanni

Department of Physiology and Biochemistry,

Faculty of Medicine and Surgery, University of Malta,

Valletta, Malta with personality disorders), aiming to invite the reader to integrate some aspects of the neurobiology of human suicidal behaviour into a model of suicide that can be used in a clinical encounter.

Keywords Suicide - Serotonin - 5-HT2 receptors · 5-HTTLP · Serotonin transporter · Schema therapy · Borderline personality disorder

\section{Introduction}

Suicide is receiving increasing attention worldwide, with many countries developing national strategies for prevention. Suicide accounts for almost $2 \%$ of deaths worldwide, and attempted suicide is more frequent than completed suicide, with a prevalence of $3.5 \%$ (Suominen et al. 2004). The definition of suicidal behaviours encompasses a broad constellation of heterogeneous entities differing not only in manifestation, but also in their background (Courtet et al. 2004).

Forms of suicidality include suicidal ideations, impulsive suicide attempts with low lethality, highly lethal failed suicide attempts and completed suicide (Bondy et al. 2000) and involve the intention to die and the lethality of method (Bondy et al. 2000). The nature of the suicidal act may range from impulsive to carefully premeditated and from aggressive/punitive or violent to non-violent or passive.

Suicide can either be attempted or completed, although an overlap has been noted given that about two-thirds of suicide victims have made one or more prior suicide attempt(s), and non-violent suicide attempters frequently change their suicide method from non-violent to violent (Rihmer 2007). Attempted suicide is a self-damaging act aimed at ending one's life resulting in failed suicide 
and suicide gesture. Failed suicide, provoked by a strong intent to die, involves careful planning and a highly lethal method, whereas suicide gesture (usually provoked by an interpersonal conflict) involves less preparation and less lethal methods with low intent to die (Mann 1998).

The great diversity of suicidal behaviours reflects their association with a range of disorders. These include major depressive disorder (MDD), substance-related disorders and personality disorders, including borderline personality disorder (BPD). Comorbidity among these disorders and between these disorders and suicide behaviour is common (Bondy et al. 2000; Dumais et al. 2005a, b). Suicide and attempted suicide are complex behaviours. A large number of proximal and distal risk factors have been identified (Hawton and van Heeringen 2009) which can be categorized into explanatory models aiming to understand suicidal individuals and facilitate suicide risk assessment. The most widely accepted risk factors for suicidal behaviour involve psychiatric-psychological and socioeconomic factors, while the biological, neurochemical and genetic contributions to suicidality have not yet been as fully elucidated.

On a neurobiological level, dysfunction of the serotonergic system has been shown to be implicated in a number of psychiatric afflictions including MDD, BPD and suicide (Oquendo and Mann 2000; Bortolato et al. 2013; Di Giovanni et al. 2008). Many studies have provided important information regarding the anatomy, development and functional organization of the 5-HT system and the alterations in this system that are present within the brain of the suicidal patient (Pandey 2013). On a psychotherapeutic level, early models have identified key determinants operating during the development of disorders or behavioural problems. Several have focused on, among other factors, the cognitive and emotional characteristics of depression and personality disorders. This conceptual approach and the empirical research motivated by such models have led to significant insights into these disorders (Ingram and Luxton 2005; Nadort et al. 2009).

Our aim is to review the scientific literature on the contribution of the serotonergic system to suicidal behaviour as well as to dysfunctional attitudes and personality traits associated with the suicidal patient. Although we will discuss data from studies investigating both suicide completers and attempters interchangeably, we acknowledge that these two phenotypes are likely to only partly share underlying aetiological and neurobiological mechanisms (Turecki et al. 2012). The association of the 5-hydroxyindoleacetic acid (5-HIAA), the 5-HT2A/2C receptors and the serotonin transporter promoter region (5-HTTLPR) polymorphism and suicidal behaviour along with animal models will be discussed. Finally, the relationship between neurobiological models and psychotherapeutic interventions for suicide prevention will be discussed with a focus on Schema
Therapy (an approach that has shown particular promise in the treatment of suicidal individuals with personality disorders), aiming to invite the reader to integrate some aspects of neurobiology of human suicidal behaviour into a model of suicide that can be used in a clinical encounter.

\section{Serotonergic function in suicide}

Cerebral spinal fluid 5-hydroxyindoleacetic acid in suicidal behaviour

Given the inaccessibility of the human brain, initial studies of the biology of suicidal behaviour and development of biomarkers focused on peripheral tissues such as cerebrospinal fluid (CSF), urine, platelets and serum. Initial evidence for the involvement of 5-HT in suicide stemmed from findings of low CSF 5-hydroxyindoleacetic acid (5-HIAA) levels in depressed suicide attempters and in the brain stems of completed suicides (Asberg 1997; Asberg et al. 1976; Banki et al. 1984; Carlsson et al. 1980; Mann and Malone 1997; Placidi et al. 2001; Roy et al. 1986; Träskman et al. 1981). Although the link between low CSF 5-HIAA and suicidality has been debated (Roggenbach et al. 2002), significantly lower levels of CSF 5-HIAA have also been reported in a meta-analysis of CSF metabolite studies in subjects who made prior suicide attempts and those who subsequently committed suicide (Lester 1995). Further investigation on the relationship between CSF 5-HIAA and prefrontal (PFC) 5-HT has shown a positive correlation between the two in autopsied subjects (Stanley et al. 1985). In addition, more recent studies have shown that suicide attempters exhibit a blunted release of prolactin in response to administration of fenfluramine, a measure of 5-HT activity (Dulchin et al. 2001; Duval et al. 2001; Malone et al. 1996; Mann 1995; Pandey 1997; Weiss and Coccaro 1997).

\section{5-HT receptor in suicidal behaviour}

With regard to 5-HT receptor dysfunction in suicide and aggression, the most studied have been the $5-\mathrm{HT}_{1}, 5-\mathrm{HT}_{2}$ subtypes (Bortolato et al. 2013; Panariello et al. 2011). We will focus on $5-\mathrm{HT}_{2}$ receptors that have been implicated in a wide variety of conditions including obesity, anxiety, depression, obsessive compulsive disorder, schizophrenia, migraine and erectile dysfunction (Di Giovanni et al. 2008, 2011).

\section{$5-\mathrm{HT}_{2 \mathrm{~A}}$ receptor in suicidal behaviour}

In vivo neuroimaging techniques provide a great opportunity to further elucidate the link between adverse 
environmental conditions, biomarkers and the symptoms or traits implicated in suicidal behaviour. Early evidence suggests that increased $5-\mathrm{HT}_{2 \mathrm{~A}}$ receptor binding in the prefrontal cortex, specifically Brodmann area 9, constitutes the most consistent post-mortem biological abnormality of suicide (Arango et al. 1990, 1992; Mann et al. 1986; Stockmeier et al. 1997; Turecki et al. 1999; Pandey et al. 2002; Stockmeier 2003). Although these abnormalities were reported as alterations in $5-\mathrm{HT}_{2}$ receptor binding, it seems as if these studies investigated $5-\mathrm{HT}_{2 \mathrm{~A}}$ receptors as ligand binding to $5-\mathrm{HT}_{2 \mathrm{C}}$ receptors (Hoyer et al. 1986). In addition, the mRNA of 5- $\mathrm{HT}_{2 \mathrm{~B}}$ receptors has low expression levels in cortex (Schmuck et al. 1994). Given that these findings were reported in studies in which diagnosis of the suicide victim was unrestricted together with the consistency noted between those studies with depressed and medication-free suicide victims (Hrdina et al. 1993; Yates et al. 1990), questions are raised concerning the extent to which this finding is associated with a specific diagnosis, a symptom cluster associated with suicide or represented a biomarker of suicidal ideation. Although the aforementioned finding was noted in studies of victims who committed suicide by violent means (Arango et al. 1990; Arora and Meltzer 1989; Mann 1996; Hrdina et al. 1993), it was unclear how this abnormality could be linked with symptomatology or personality traits. A recent autopsy study has proposed that suicide victims dying by violent means exhibited greater planning of suicide or a predisposition towards aggressive behaviour (Dumais et al. 2005a, b). Since it is much easier to recruit subjects with specific diagnoses in vivo, most neuroimaging studies of $5-\mathrm{HT}_{2 \mathrm{~A}}$ receptors focused upon three diagnostic areas in relation to 5- $\mathrm{HT}_{2 \mathrm{~A}}$ receptors: MDD, BPD and antisocial personality disorder (APD).

MDD and prefrontal 5- $\mathrm{HT}_{2 \mathrm{~A}}$ binding in suicidal behaviour

Neuroimaging studies of $5-\mathrm{HT}_{2 \mathrm{~A}}$ receptors in depressed and healthy samples seem to be inconsistent with the postmortem findings as many of these between-group comparisons reported a regional decrease in $5-\mathrm{HT}_{2 \mathrm{~A}}$ binding, which could probably be attributed to selective serotonin reuptake inhibitor (SSRI) treatment (Dhaenen et al. 1992; Biver et al. 1997; Attar-Levy et al. 1999; Mintun et al. 2004; van Heeringen et al. 2003; Audenaert et al. 2001). Since these initial studies sampled people with recent antidepressant treatment, the initial impression was that regional 5- $\mathrm{HT}_{2 \mathrm{~A}}$ binding tended to be reduced in MDD. However, further studies on depressed subjects not being in antidepressant treatment failed to reveal any differences compared to healthy controls (Meyer et al. 1999; Meltzer et al. 1999). Specifically, Meyer et al. (1999) sampled medication-free ( $>6$ months) subjects with no comorbid psychiatric afflictions, in the midst of a major depressive episode (MDE) from early onset MDD and by applying $\left[{ }^{18} \mathrm{~F}\right]$ setoperone, a very good radioligand for imaging $5-\mathrm{HT}_{2 \mathrm{~A}}$ receptors, no difference in prefrontal cortex $5-\mathrm{HT}_{2 \mathrm{~A}}$ binding was found as compared to healthy controls.

The inconsistency between studies of suicide victims and neuroimaging studies of MDEs could be attributed to the presence of a subgroup of subjects with MDEs who have the biological abnormality reported in suicide victims (e.g. low extracellular serotonin). $5-\mathrm{HT}_{2 \mathrm{~A}}$ receptor density has an inverse relationship with extracellular serotonin levels, i.e. the density of $5-\mathrm{HT}_{2 \mathrm{~A}}$ receptors in the cortex increases after chronic serotonin depletion and decreases after chronically raising extracellular serotonin (O'Regan et al. 1987; Todd et al. 1995). The symptom used to identify this subgroup was the elevated pessimism (dysfunctional attitudes) observed during MDEs. There is a modest level of dysfunctional attitudes in health, which increases to a variable extent during depressive episodes (Simons et al. 1986; Fava et al. 1994). Greater pessimism during MDEs is an important symptom that contributes to the generation of sad mood and is targeted by cognitive therapy as well as SSRI treatment (Simons et al. 1986; Fava et al. 1994). Increasing extracellular serotonin after administration of intravenous d-fenfluramine is associated with a strong shift in dysfunctional attitudes towards optimism in healthy individuals (Meyer et al. 2003). This argues that among the many roles of serotonin, one of them is to modulate dysfunctional attitudes in humans. Both the anterior cingulate cortex and dorsolateral and medial PFC participate in functions related to optimism and pessimism (Sharot et al. 2007; Mitterschiffthaler et al. 2008; Elliott et al. 2002).

A strong correlation has been observed between the severity of dysfunctional attitudes (pessimism) and elevation in cortex $5-\mathrm{HT}_{2 \mathrm{~A}}$ binding potential, reflecting specific binding relative to free and non-specific binding $\left(\mathrm{BP}_{\mathrm{ND}}\right)$. Moreover, cortex 5- $\mathrm{HT}_{2 \mathrm{~A}} \mathrm{BP}_{\mathrm{ND}}$ was significantly elevated in subjects with MDE and severe pessimism (Meyer et al. 2003). There was a strong, significant correlation between severity of pessimism and prefrontal cortex $5-\mathrm{HT}_{2 \mathrm{~A}} \mathrm{BP}_{\mathrm{ND}}$. In a separate study of a large sample of healthy subjects, two personality facets related to pessimism (vulnerability and anxiety) were also positively correlated with prefrontal cortex, temporal cortex and left insula 5- $\mathrm{HT}_{2 \mathrm{~A}} \mathrm{BP}_{\mathrm{ND}}$ (Frokjaer et al. 2008).

The investigations correlating severity of dysfunctional attitudes with greater 5- $\mathrm{HT}_{2 \mathrm{~A}} \mathrm{BP}_{\mathrm{ND}}$ (Meyer et al. 2003) are highly consistent with post-mortem investigations reporting greater $5-\mathrm{HT}_{2 \mathrm{~A}}$ receptor density in the prefrontal cortex of suicide victims. Fifty per cent of suicide victims suffer from MDD (Robins et al. 1959). The dysfunctional attitudes scale (DAS) is highly correlated with hopelessness measured with the Beck Hopelessness Scale (Cannon 
et al. 1999; Norman et al. 1988). Given that hopelessness is a risk factor for suicide (Beck et al. 1985, 1989), it is plausible that investigations of suicide victims reporting increased 5- $\mathrm{HT}_{2 \mathrm{~A}} \mathrm{BP}_{\mathrm{ND}}$ sampled depressed subjects with a greater severity of pessimism.

Personality disorders (BPD/APD) and prefrontal $5-\mathrm{HT}_{2 \mathrm{~A}}$ binding in suicidal behaviour

BPD and APD constitute two other psychiatric conditions on which the studies of suicide victims have focused (Barraclough et al. 1974; Robins et al. 1959; Brodsky et al. 1997). 5-HT $2 \mathrm{~A}$ binding in medication-free BPD patients showed no difference in the prefrontal cortex (Meyer et al. 2003); however, an increase in 5- $\mathrm{HT}_{2 \mathrm{~A}}$ binding in the hippocampus was found (Soloff et al. 2007). $5-\mathrm{HT}_{2 \mathrm{~A}}$ binding in aggressive individuals revealed no group difference in any region, but an age interaction such that $5-\mathrm{HT}_{2 \mathrm{~A}}$ binding tended to increase considerably more with age in individuals with aggression (Meyer et al. 2008). This age-related effect might represent an index of differential change in pyramidal cell loss, since most $5-\mathrm{HT}_{2 \mathrm{~A}}$ receptors are found in apical dendrites of pyramidal cell neurons and the pattern of loss of pyramidal cells matches the loss in 5- $\mathrm{HT}_{2 \mathrm{~A}}$ receptors with age (Jacobs et al. 1997; Jakab and GoldmanRakic 1998; Santana et al. 2004). Greater 5-HT ${ }_{2 \mathrm{~A}}$ receptor binding has also been reported recently in the orbitofrontal cortex of impulsively aggressive personality disordered individuals (Rosell et al. 2010). However, this finding should be treated with caution as participants were not subjected to urine screening for substance abuse, a condition commonly comorbid with aggression. Such substances may bias 5- $\mathrm{HT}_{2 \mathrm{~A}}$ receptor binding (Bubar and Cunningham 2008). Consequently, among the investigations of 5- $\mathrm{HT}_{2 \mathrm{~A}}$ binding, there is support for increased binding in older individuals with aggression throughout the cortex and in the orbitofrontal cortex in people with aggression.

The evidence of greater 5- $\mathrm{HT}_{2 \mathrm{~A}}$ density in the PFC of suicide victims in post-mortem studies should be reinterpreted through the prism of diagnostic and symptomspecific findings from neuroimaging studies of $5-\mathrm{HT}_{2 \mathrm{~A}}$ binding. MDD with high levels of pessimism is associated with greater prefrontal cortex $5-\mathrm{HT}_{2 \mathrm{~A}}$ binding. Half of the suicide victims have MDD and hopelessness (highly correlated with pessimism), which is associated with heightened risk of suicide (Beck et al. 1985, 1989; Cannon et al. 1999). The diagnosis of BPD does not contribute to the finding of greater prefrontal cortex 5- $\mathrm{HT}_{2 \mathrm{~A}}$ density in suicide victims since no change in prefrontal $5-\mathrm{HT}_{2 \mathrm{~A}} \mathrm{BP}_{\mathrm{ND}}$ was found (Meyer et al. 2003; Soloff et al. 2007). In those with aggressive behaviour, a subgroup of subjects older than age 34 show a similar neurobiological finding and would be expected to also contribute to the original findings of greater prefrontal 5- $\mathrm{HT}_{2 \mathrm{~A}}$ density in suicide victims (Meyer et al. 2008; Rosell et al. 2010).

$5-\mathrm{HT}_{2 \mathrm{~A}}$ receptors in aggression and suicide

Impulsive and aggressive traits are postulated to be part of the diathesis for suicidal behaviour (Mann et al. 1999). High levels of aggressive behaviour have been associated with suicidal behaviour, especially lethal suicide attempts. Impulsive behaviour has been shown to be highly related to non-fatal suicide attempts (Oquendo et al. 2004). As mentioned earlier, low levels of 5-HT have been implicated in impulsive violence and aggression in studies including low CSF 5-HIAA in individuals with a lifetime history of aggressive behaviour with personality and other psychiatric disorders (Brown and Goodwin 1986; Stanley et al. 2000). Low levels of 5-HT have also been associated with a blunted prolactin response to serotonin-releasing agent fenfluramine in personality disorder patients (Coccaro et al. 1989, 1995). Increased levels of 5- $\mathrm{HT}_{2 \mathrm{~A}}$ receptor binding correlated with aggressive behaviour in personality and other psychiatric disorder patients (McBride et al. 1994; Coccaro et al. 1989). A role for serotonergic function in aggressive and to a lesser extent, impulsive behaviour, is well documented (Ryding et al. 2006; Congdon et al. 2008), consistent with observations that low SERT binding associated with suicide appears to be concentrated in the ventromedial PFC and anterior cingulate regions, which play a role in mediating inhibition and restraint (Arango et al. 1995; Mann et al. 2000). However, using post-mortem brain tissue, platelets, and DNA from suicide completers and attempters has not provided unequivocal evidence for a pre-eminent role for the SERT in the pathophysiology of suicide (Purselle and Nemeroff 2003).

\section{$5-\mathrm{HT}_{2 \mathrm{C}}$ receptors in aggression and suicide}

Despite the intense research on $5-\mathrm{HT}_{2 \mathrm{C}}$ receptors showing its pivotal involvement in different neuropsychiatric disorders, only recently has the first selective agonist lorcaserin (Beliviq, Arena Pharmaceutical) advanced into the clinic, it was approved in 2013 by FDA for the treatment of obesity (Berlie and Hurren 2013). This paradoxical situation is due to the lack of selective pharmacological tools capable of overcoming the high degree of homology among 5-HT2 receptors and, above all, the complexity of $5-\mathrm{HT}_{2 \mathrm{C}}$ signalling. Indeed, the $5-\mathrm{HT}_{2 \mathrm{C}}$ receptor is the only known $\mathrm{G}$ protein-coupled receptor (GPCR) subject to a form of post-transcriptional modification known as RNA editing (Di Giovanni et al. 2006). This is a process in which specific adenosine residues are converted to inosine resulting in functional recoding of the mRNA that can generate up to 24 different protein isoforms with distinct 
functional properties. Post-mortem, animal and pharmacological studies have suggested that 5 -HT2C receptor and their altered RNA editing is involved in the pathophysiology of mental disorders including aggression and suicide, although results remain inconsistent (Panariello et al. 2011; Bortolato et al. 2013; Di Giovanni et al. 2006, 2011). For instance, an increased density of prefrontal cortex $5-\mathrm{HT}_{2 \mathrm{C}} \mathrm{R}$ mRNA (Pandey et al. 2006) and differences in pre-mRNA editing of these receptors between control subjects and suicidal victims have been found (Gurevich et al. 2002; Dracheva et al. 2008). Consistently, full edited 5- $\mathrm{HT}_{2 \mathrm{C}} \mathrm{R}$ receptor mice displayed enhanced anxiety-like behaviour in response to the preferential $5-\mathrm{HT}_{2 \mathrm{C}}$ agonist, m-chlorophenylpiperazine (mCPP; Di Giovanni et al. 2000), in the social interaction test and increase in freezing behaviours in reaction to an innately aversive ultrasonic stimulus (Martin et al. 2013). These authors suggested that enhanced $5-\mathrm{HT}_{2 \mathrm{C}}$ receptor editing through interference from alternative splicing would lead to a deficit of truncated receptors that normally exert a dominant negative effect on the addressing of the full-length $5-\mathrm{HT}_{2 \mathrm{C}}$ receptor protein to the membrane (Martin et al. 2013). Moreover, it is known that the pharmacological stimulation of $5-\mathrm{HT}_{2 \mathrm{C}}$ receptors reduces aggressive responses and enhances the display of submissive behaviour (Rosenzweig-Lipson et al. 2007; Dekeyne et al. 2012; Harvey et al. 2012). These effects, however, may result from a general enhancement in social anxiety caused by drugs acting at $5-\mathrm{HT}_{2 \mathrm{C}}$ receptors capable of inducing panic attack in humans (Charney et al. 1987). Indeed, increased neuroendocrine and anxiety responses to $\mathrm{mCPP}$ were observed in some individuals with MDD (Ghaziuddin et al. 2000). In addition, an increased in response to $\mathrm{mCPP}$ in cerebral blood flow of left frontal of individuals carrying the $5-\mathrm{HT}_{2 \mathrm{C}}$-Cys-23-Ser polymorphism in the $5-\mathrm{HT}_{2 \mathrm{C}}$ coding region was observed (Kuhn et al. 2004). In contrast, most studies failed to identify significant associations among polymorphisms of this receptor and suicidal attempts (Zhang et al. 2008; Turecki et al. 2003; Serretti et al. 2007, 2009; Arias et al. 2001), completed suicide (Stefulj et al. 2004), the severity of suicidal behaviours (De Luca et al. 2008; Di Giovanni et al. 2011; Panariello et al. 2011) or suicide risk and deliberate self-harm (Pooley et al. 2003). On the other hand, the latest available study detected a significant association between completed suicide and the variants of $5-\mathrm{HT}_{2 \mathrm{C}}-\mathrm{Cys}-23$-Ser polymorphism but not the mutation G-995A (promoter region) in the $5-\mathrm{HT}_{2 \mathrm{C}}$ of Slovenian suicide victims (Videtic et al. 2009).

Since $5-\mathrm{HT}_{2 \mathrm{C}}$ receptors are preferentially expressed on GABAergic interneurons (Serrats et al. 2005; Boothman et al. 2006; Liu et al. 2007; Di Giovanni et al. 2001), their hyperactivity and/or increase density/editing lead to an increase in the GABAergic function in areas such as the frontal cortex, other limbic structures and the raphé nuclei determining a decrease in 5-HT turnover seen in aggression and suicide (Bortolato et al. 2013; Oquendo and Mann 2000).

Serotonin transporter imaging and post-mortem studies of suicide victims

In addition to the post-mortem studies of serotonin transporter (5-HTT) binding in depression (with or without concurrent suicide), decreased 5-HTT binding has been reported in the ventral prefrontal cortex associated with suicide, independent of diagnosis (Mann et al. 2000; Arango et al. 1995). Comparison between suicide victims with a history of depression and suicide victims without a history of depression yielded significantly lower 5-HTT binding in ventral prefrontal cortex in the suicide victims (Mann et al. 2000). Additionally, both groups of suicide victims had lower ventral prefrontal cortex 5-HTT binding as compared to non-suicide controls.

Further neuroimaging investigations have identified the conditions associated with decreased global 5-HTT binding describing a region-specific pattern that matches a predominant lower level of ventral prefrontal cortex binding (Meyer et al. 2001, 2004). Global reductions in 5-HTT binding may be observed following antidepressant treatment (Meyer et al. 2001, 2004; Suhara et al. 2003), in fall/ winter season relative to spring/summer (Praschak-Rieder et al. 2005), as well as following ecstasy abuse, where a reduction in 5-HTT binding seems to be selectively affecting cortical regions including the striatum and midbrain (McCann et al. 2005; Selvaraj et al. 2009). A similar region-specific effect has been recently reported in studies with patients suffering from obsessive-compulsive disorder (OCD) where the lowest 5-HTT binding was noted in ventral prefrontal cortex (Matsumoto et al. 2010; Reimold et al. 2007). Given that substance abuse and anxiety disorders are correlated with higher risk for suicide, it could be argued that ecstasy abuse and OCD could contribute to the diminished ventral prefrontal cortex 5-HTT binding in suicide completers (Mann et al. 2000).

Further experimentation supports the hypothesis that 5-HTT binding in impulsivity, as well as other maladaptive behaviours related to risk for suicide, is associated with 5-HTT binding reduction. Studies on early maternal separation in peer-reared rhesus monkeys (an animal model which will be discussed in another section of this review), who later exhibited aggressive and impulsive behaviour, have reported loss of 5-HTT binding restricted in areas including the midbrain, thalamus, caudate, putamen and anterior cingulate cortex, but not the prefrontal cortex (Ichise et al. 2006). Neuroticism, a personality trait which may involve impulsivity, has been positively correlated with thalamic 5-HTT binding (Takano et al. 2007) and 
negatively associated with openness to values, the latter of which has shown a negative correlation with 5-HTT binding in subcortical regions (Kalbitzer et al. 2009). Aggression has also been linked with low levels of 5-HTT binding in the anterior cingulate cortex (Frankle et al. 2005) but with greater 5-HTT binding in brain stem of people with BPD (Koch et al. 2007). The degree to which these binding changes take place in the prefrontal cortex cannot be assessed due to the radiotracing methods utilized in these studies. Neuroimaging studies of 5-HTT binding in impulsivity and related conditions have not provided evidence confirming the ventral prefrontal cortex pattern of 5-HTT binding loss reported by post-mortem studies targeting this specific region (Mann et al. 2000; Arango et al. 1995).

Serotonin transporter in personality traits linked with suicide

Genetic studies focusing on 5-HT-related genes in search of genetic markers of suicide suggest that the 5-HT transporter length polymorphic region (5-HTTLPR) polymorphism of the serotonin transporter gene is strongly related to suicide (Costanza et al. 2013; Gonda et al. 2011). The short (s) allele of the 5-HTTLPR is associated with reduced serotonin transporter (5-HTT) protein availability and function (Canli and Lesch, 2007) compared with the long (L) form. The presence of at least one $\mathrm{s}$ allele has been proposed as a predictor of suicidal behaviour (Bondy et al. 2006). Considering the different suicidal phenotypes, including a review of related meta-analyses, the s allele seems to be associated with impulsive and aggressive suicidal behaviours and completed suicide (Bondy et al. 2000) and violent (Bayle et al. 2003; Bellivier et al. 2000; Courtet et al. 2001) as well as repeated suicide attempts (Courtet et al. 2004). A recent meta-analysis suggests that 5HTTLPR and the RS1800532 (tryptophan hydroxylase variant) polymorphisms are significantly associated with suicide attempts, but not associated with completed suicides (Clayden et al. 2012).

The presence of the s allele of the 5HTTLPR has been associated with the development of BPD (Ni et al. 2006). A recent study has shown that among a broad range of psychiatric disorders, patients with BPD are at particularly high risk for suicide completion (Qin 2011) making up 9-33\% of the total number (Pompili et al. 2005). Two meta-analyses (Samual and Widiger 2008; Saulsman and Page 2004) have found consistent high positive correlations between various measures of BPD and neuroticism as defined and measure by the NEO PI-r (Costa and McCrae 1995). In fact, BPD has the strongest and most consistent correlation with neuroticism among the personality disorders with BPD having significant correlations with all six of its facets. Thus, neuroticism can be seen as a core trait underlying BPD (Samual and Widiger 2008; Saulsman and Page 2004). Neuroticism is among the traits that consistently have been associated with suicide ideation, attempts and complete suicide (Brezo et al. 2006). Lesch et al. (1996) found a significant correlation between the $\mathrm{s}$ allele and neuroticism. This investigation inspired many subsequent attempts at replication. The results have been inconsistent with studies supporting (Gonda et al. 2009) and not supporting (Willis-Owen et al. 2005) this finding. The majority of these studies were underpowered, with sample sizes being small relative to what is needed to draw conclusions based on the small effect size that can be attributed to a single gene. Two studies that were adequately powered (Willis-Owen et al. 2005; Terracciano et al. 2009) did not find a correlation, however, several meta-analyses did (Schinka et al. 2004; Sen et al. 2004; Munafo et al. 2005). The latter two investigations clarified that finding a correlation was dependent upon the method of meta-analysis being used. Genetic variations other than those associated with 5-HTTLPR have been explored but to date, after a decade of effort, no others have been found to correlate with neuroticism, underscoring the importance of the link between the two (Canli 2008). Primates who carry the homologue of the s allele express phenotypic features of neuroticism (e.g. increased anxiety and reduced social interaction; Hariri 2006).

Another line of investigation has looked at the possibility that the $\mathrm{s}$ allele is not itself correlated with negative affect but interacts with adversity, leading to neuroticism or such states as depression or anxiety in the face of negative life events. These studies were also initially leading to inconsistent findings. A recent large-scale, highly powered study (Middeldorp et al. 2010) and two meta-analyses (Munafo et al. 2009; Risch et al. 2009) concluded that the $\mathrm{s}$ allele did not moderate the interaction between negative life events and neuroticism. However, Uher and McGuffin (2009) have shown that the method of assessment of environmental adversity led to these negative results. When self-report measures were used, no moderating effect was found, but when detailed interview-based measures were used, the s allele was indeed found to have a moderating effect. This moderating effect has been clearly demonstrated in non-human primates (rhesus macaques). Infant primates who were deprived of adequate maternal care (i.e. peer raised) and who carried the s allele manifested heightened anxiety and depression, reduced engagement in play, greater aggression and increased alcohol consumption relative to L allele carriers (Champoux et al. 2002; Meaney 2001; Nelson et al. 2009). Mother rearing eliminated the differences between the two groups. Studies that have demonstrated this interaction in humans have found that children who carried the s allele who were exposed to emotional and or physical abuse showed increased levels 
of anxiety, depression and cortisol secretion (Caspi et al. 2003; Stein et al. 2008; Taylor et al. 2006). Human infants who carry the s allele and who experience poor childrearing conditions are more likely to develop a negative emotional temperament (Auerbach et al. 2001). Individuals diagnosed with BPD or APD almost always suffer from severe childhood adversity. The interaction between these adverse experiences and the $\mathrm{s}$ allele is demonstrated by the finding that the relative risk of developing BPD or APD has been shown to increase by a factor of 2 for each short allele the individual carries (Gunderson and Lyons-Ruth 2008).

It is important to note that the impact of the $\mathrm{s}$ allele goes beyond an influence on anxiety and depression. It has been associated with bipolar and unipolar affective disorder, OCD, eating disorders, attention-deficit/hyperactivity disorder, neurodegenerative disorders and of particular importance in relation to the current discussion, suicide (Murphy and Lesch 2008). The s allele has been found to be associated with general impulsivity in the context of a broad range of emotionally evocative situations when the individual has been exposed to adverse environments in childhood. The combination of greater impulsivity and heightened levels of emotional pain associated with the s allele $\times$ childhood adversity interaction strengthens the link with suicidality. This combination is reflected in the significant and consistent negative correlation found between the Conscientiousness scale of the NEO PI-r and BPD and the strong positive correlations between neuroticism and BPD (Samual and Widiger 2008; Saulsman and Page 2004). Negative scores on the Conscientious scale reflect difficulties with restraint and impulse control.

The vast majority of this research has been conducted within the diathesis-stress framework and, as a result, has not examined these interactions from the vantage point of what is called the differential susceptibility or "plasticity hypothesis" (Belsky and Pluess 2009). The diathesis-stress model focuses solely on the negative impact stress can have when impinging on an area of vulnerability. The plasticity hypothesis suggests that some individual differences can lead to bad outcomes in the face of adversity or very good outcomes in the context of enriched environments. Metaphorically what was viewed as a source of fragility and as operating like glass in the face of a stone is now seen as something more like clay that can form a deep impression for the better or worse. Looking at the impact of both positive and negative life events on the link between the $\mathrm{s}$ allele and neuroticism would allow for an examination of the full scope of its potentially moderating effect. On the positive side, carriers of two short alleles have been found to have more pulvinar neurons (Young et al. 2007). Pulvinar neurons are involved in the processing of visual signals sent to the limbic system via a subcortical route. More neurons mean a stronger connection and may be associated with a greater capacity to detect the emotional context of an environment. Short allele carriers express greater sympathetic reactivity when observing another person receiving a shock (Crişan et al. 2009), suggesting a possible link to a greater capacity for empathy. In another study, it was found that seeing a favourite person led to significantly higher amygdala activity in short allele carriers suggesting a higher reward value of positive interpersonal experience (Matsunagaa et al. 2010). Homberg and Lesch (2011) have reviewed the many cognitive and emotional advantages that correspond to the greater sensitivity and emotional responsiveness that has been correlated with the s allele. They hypothesize that these advantages may counterbalance or completely offset the disadvantages and may also be a contributor to some of the inconsistent findings referred to above.

Working from the same premise, Pluess et al. (2010) studied the interaction between negative and positive life events in relation to neuroticism in individuals homozygous for $\mathrm{s}$ alleles and $\mathrm{L}$ alleles. Consistent with the plasticity hypothesis, they found that those with $\mathrm{s}$ alleles who experienced more negative life events had higher neuroticism scores and those experiencing more positive life events had lower neuroticism scores. Those with $\mathrm{L}$ alleles had consistent scores on neuroticism regardless of the number of positive or negative life events. Thus, neuroticism may be a more stable trait for those with the $\mathrm{L}$ allele and less so for those with an s allele. It also may be that those with $\mathrm{s}$ alleles are more likely to be negatively impacted by a toxic childhood, develop maladaptive schemas and exhibit a behavioural and affectional pattern that will be associated with higher neuroticism scores. As noted above, we know that $\mathrm{s}$ allele carriers are more likely to develop BPD when exposed to toxic environments. This greater degree of responsiveness to the environment is reflected in the finding that human and primate s allele carriers have been found to be more responsive at rest in many cortical sites (Canli 2008).

Another study supporting the plasticity hypothesis was conducted by Antypa and van der Does (2010). They asked 250 university students about experiences of emotional abuse in childhood. Emotional abuse is a frequently reported occurrence among patients suffering from BPD. Cognitive reactivity to sad mood was assessed using the Leiden Index of Depression Sensitivity Scale. This measures habitual negative cognitive patterns and yields scores that remain high even when symptoms are low and thus overlaps significantly with the notion of an early maladaptive schema described in the last section of this review (4. Bridging neurobiological models with clinical psychotherapy). The results confirmed the plasticity hypothesis. Short allele carriers whose scores were very low on a measure of childhood emotional abuse had extremely low scores 
on the measure of cognitive vulnerability to depression and extremely high scores when they reported high scores on measures of abuse. Long allele carriers had moderate scores no matter what level of abuse they reported. Put another way, the short allele carriers were able to benefit far more from a good childhood than the long allele carriers. It is important to note that while these recent findings are intriguing, replication with a well-powered study is needed to confirm or refute these observations. It is estimated that a sample size over 1,000 will be needed to have $80 \%$ power at a significance level of $p=0.50$ (Munafo et al. 2009).

On a neural level, a meta-analysis found a consistent correlation between the s allele and greater amygdala reactivity to many forms of negative stimuli relative to neutral cues. This included faces expressing fear and anger, and negative scenes and words (Canli and Lesch 2007; Hariri 2006). The strength of this correlation was about six times greater than that found on self-report measures. Thus, it appears that when variables closer to the genetic level (endophenotypes) are studied, the links are stronger than those found on the phenotypic level (e.g. those assessed by the NEO PR-r). Human s allele carriers have also been found to have increased anterior cingulate activity, especially in response to social threat (Jahn et al. 2010; Way and Taylor 2010). This reactivity was associated with greatly increased cortisol secretion.

The $\mathrm{L}$ allele and the associated efficient serotonergic functioning may lead to greater self-reliance with more affective regulation occurring within one's own synapses. The s-allele, associated with less efficient serotonergic functioning, may lead to an adaptive strategy that draws more on deep and enriched ongoing attachments to regulate affect. We could view this as emphasizing regulation across a "social synapse". This is a genetic variation that goes deep into our past as a species and, interestingly, humans and rhesus macaques are the only two species which have it. Humans and rhesus macaques are known as the "weed" species since both proliferate wherever they are placed in the world. It seems that both adaptive strategies (self-reliance and strong attachments) are important to the collective whole in both of these species and that the latter flourishes in supportive and nurturing interpersonal environments and leads to considerable emotional suffering including despair and suicidal behaviour in toxic interpersonal contexts.

\section{Animal models of suicide}

Animal models are formidable tools to investigate the aetiology of an illness, its course, potential treatment (Collado and Serrano 2010; Lanzas et al. 2010) and the neurobiology of associated behaviour (McKinney 2001). No convincing animal models of suicide have been developed to date, although many researchers have tried to identify suicide in non-human species in the natural setting (Preti 2007). A range of suicidal behaviour in animals has been claimed. For example, animals in captivity or separated from their master have been reported to starve to death voluntarily (Preti and Miotto 2005; Ramsden and Wilson 2010) or exhibit self-destructive behaviours (Crawley et al. 1985); uncontrolled anxiety provoking situations including isolation, separation and confinement have been reported to result in self-endangering behaviours in primates (Kraemer and Clarke 1990; Tiefenbacher et al. 2005); monkeys in reared isolation showed higher risk of self-endangered behaviour in adulthood (Crawley et al. 1985). This latter finding parallels the impact of childhood abuse or neglect on the risk of suicide in humans (Evans et al. 2005; Brodsky and Stanley 2008). However, the degree to which such selfendangering behaviours in animals resemble self-harming behaviour in humans is debatable.

While modelling suicidal behaviour in animals fails to reproduce the role of will and intention in suicide mechanics, current animal models are making an effort to forge a tighter link by studying each step along the chain of behaviours leading to suicide in humans (for review on animal models of suicide, see Preti 2011). Among the several distinct animal models of suicide, learned hopelessness and maternal deprivation seem to be particularly promising.

As discussed earlier, hopelessness and pessimism are major cognitive factors for suicide, and hopelessness per se has emerged as a predictor of suicide attempt and completion in clinical samples (Beck et al. 1985). The learned helplessness paradigm (Seligman 1972) is considered as an analog of human hopelessness (Krishnan and Nestler. 2008). These studies have involved series of inescapable electrified foot shocks as aversive stimuli, after which a subgroup of animals stops any attempt to escape. Following retesting after some delay, some animals try to escape again, while others indefinitely exhibit despairlike behaviour, failing to escape. Although this model offers good face validity, as many symptoms in humans (weight loss, sleep disturbances, distorted perception of pleasure, etc.) can be modelled in animals once learned helplessness has established, its ecological validity (i.e. correspondence with a real situation in humans) is poor as the model utilizes painful stimuli to produce helplessness. Interestingly, all antidepressants are effective in reversing the helplessness within 3-5 days of administration, compared to a 2-3 week delay in humans.

Turning to the maternal deprivation model, it has been found that early adverse life events (i.e. childhood abuse or neglect) and disrupted parenting are associated with an increased risk for psychopathology and suicidal behaviour in adolescence and adulthood (Agerbo et al. 2002; Lu et al. 2008; Afifi et al. 2009). Maternal deprivation (Lovic et al. 
2001; Gonzalez et al. 2001) in rodents has been used as a model of human disrupted parenting. Studies have shown that maternal separation leads to an increase in the typical markers of stress (Walker et al. 1991) and to reduced activity of the main inhibitory neurotransmitters in the brain (Newport et al. 2002). Moreover, female offspring separated from their mothers showed aberrant maternal care in adulthood (Lovic et al. 2001; Gonzalez et al. 2001). Maternally deprived monkeys exhibited depressive-like symptoms during development, including low CSF noradrenaline concentrations (Kraemer et al. 1991), increased self-administration of alcohol (Fahlke et al. 2002) and self-endangering behaviour (Kraemer and Clarke 1990; Tiefenbacher et al. 2005). All of these findings lend support to the face and predictive validity of this model regarding the main correlates of major depression [i.e. comorbidity with alcohol abuse (Grant and Harford 1995) and increased risk of self-harming behaviour (Angst et al. 2005; Tondo et al. 2008)].

Given the difficulties in animal modelling, an intermediate phenotype in the animal must be specifically tested for validity and reliability (Geyer and Markou 1995; Boulougouris et al. 2009). Isolating and studying relevant endophenotypes will also be important. This will involve a focus on intermediate and behavioural markers proximal to genes (Gottesman and Gould 2003). A number of investigators have begun this process focusing on rhesus macaques. This population is of particular importance in animal modelling since they share over $98 \%$ of their genetic material with humans, and as mentioned above, rhesus macaques are linked with humans in terms of a number of key genetic polymorphisms. Since rhesus macaques' early development involves a strong, exclusive, unique and enduring bond between mother and infant that has a high degree of overlap with Bowlby's (1969) characterization of human mother-infant attachment, this work has direct relevance to the maternal deprivation model.

Peer-only (PO) rearing (maternally deprived) has been found to lead to monkeys that, at a phenotypic level, are highly anxious, aggressive and impulsive and on a neuroendocrine (HPA) level exhibit more extreme responses to social separation (Suomi 1997; Dettmer et al. 2012). They have lower levels of CSF 5-HIAA concentrations than mother-reared monkeys from early infancy to later adulthood (Shannon et al. 2005; Higley and Suomi 2011) and have significantly different peripheral measures of neurotrophic factors NGF and BDNF (Cirulli et al. 2009) and as adolescents and young adults consume significantly more alcohol than their mother-reared counterparts during a "happy hour" situation (Higley et al. 1991; Fahlke et al. 2002). Neuroimaging studies have also shown the POreared monkeys to differ significantly in brain function and structure (Doudet et al. 1995; Ichise et al. 2006; Spinelli et al. 2009). Finally, major differences have been found in genome-wide expression in leucocytes between PO-reared and mother-reared monkeys (Cole et al. 2012). Deprivation of adequate maternal care clearly has profound negative consequences for rhesus monkeys at phenotypic levels as well as neuroendocrine output, neurotransmitter metabolism, brain structure and function and even genome-wide expression. These consequences are linked to risk factors associated with suicide (e.g. high emotional reactivity, aggression, impulsivity and increased alcohol consumption).

Studies of this population examining the interaction between maternal deprivation and genetic polymorphisms have led to several dramatic discoveries that contribute to animal models of suicidal behaviour and have a bearing on prevention and treatment. These discoveries, in line with the plasticity hypothesis described above, have demonstrated that when monkeys born with so-called risk alleles [such as the short allele of the 5-HTT or the less functionally efficient MAOA allele, in addition to polymorphisms in the corticotrophin releasing factor (CRH) 2A gene, the neuropeptide Y (NPY) gene and the mu opioid receptor gene] are deprived of adequate maternal care, they develop the range of negative consequences outlined above but when monkeys with these less efficient variants have normal mothering not only do they develop normally but in some ways (e.g. consuming less alcohol during happy hours) function better than their $\mathrm{L}$ allele counterparts. Thus, these alleles seem to be a risk factor in depriving or harsh environments and a protective factor in benevolent environments (Suomi 2011). The potential benefits of these less efficient variants are most likely underappreciated at present due to the fact that these studies, except for one that will be discussed later, have not been assessing the impact exceptionally good mothering over and above normal mothering has on these polymorphisms. The plasticity hypothesis would predict that these alleles have evolved in a way that capitalizes on this difference.

While endophenotypes, such as those discussed above, have been proposed as physiological and behavioural markers and important gene $\times$ environment interactions identified that relate to susceptibility to a psychiatric disorder (Hitzemann 2000; Nestler and Hyman 2010), endophenotypes for each link in the suicidal behaviour chain have yet to be identified. Clarification of clinical and psychotherapeutic models of suicidal behaviour is a prerequisite for the implementation of valid and reliable animal models.

\section{Bridging neurobiological models with clinical psychotherapy}

Different aspects of suicidality that have been associated with serotonergic modulation have been the target of several 
Table 1 Domains and early maladaptive schemas (EMS) of schema therapy [taken and adapted from Lockwood and Perris (2012)]
Disconnection and rejection

Typically arises from parenting that is detached, cold, rejecting, withholding, explosive, unpredictable or abusive

Impaired autonomy and performance

Typically arises from parenting that is under or overprotective, enmeshed and does not help to build competent functioning outside of the family

\section{Extreme conscientiousness}

Typically arises from parenting that is based on conditional approval, is controlling, emphasizes status and appearance, or emphasizes rigid rules and expectations about performance and/or ethical behaviour

Impaired limits

Typically arises from parenting that is permissive, overindulgent, fails to provide structure and direction and/or imparts a sense of superiority
Mistrust/abuse

Defectiveness/shame

Emotional deprivation

Social isolation/alienation

Emotional inhibition

Abandonment/instability; primary

Vulnerability to harm and illness Dependence/incompetence Enmeshment/undeveloped self Abandonment/instability; secondary Subjugation Failure

Self-sacrifice

Unrelenting standards

Entitlement

Insufficient self-control psychotherapeutic approaches. Hopelessness can be conceptualized as a relatively stable schema incorporating negative expectations concerning the future. Several techniques have been developed as a part of cognitive behavioural therapy (CBT) in order to challenge and modify negative core beliefs. Problem-solving techniques constitute part of CBT as well. Both cognitive therapy (Rush et al. 1982) and problem-solving training (Salkovskis et al. 1990) have been found to reduce hopelessness. Dialectical behavioural therapy (DBT) is a form of CBT developed by Linehan for the treatment of patients with BPD and suicidal behaviour. According to Linehan et al. (1993), BPD is primarily a dysfunction of the emotion regulation system which results from biological irregularities combined with certain dysfunctional environments, as well as from their interaction and transaction over time. Patients with BPD experience enduring aversive states with impulsive, suicidal behaviours appearing to be behavioural solutions to intolerably painful emotions (Linehan et al. 1993). The effectiveness of DBT in reducing suicidal behaviour has been demonstrated by Linehan et al. (1991) who found that a group of BPD patients who received DBT (1) had fewer incidences of parasuicide and less medically severe parasuicides, (2) were more likely to stay in individual therapy and (3) had fewer inpatient psychiatric days, in comparison with a treatment as usual group. At the initial 6-month follow-up, DBT subjects had significantly less parasuicidal behaviour, less anger and better self-reported social adjustment. At the final 6-month follow-up, DBT subjects were found to have significantly fewer psychiatric inpatient days and better interviewer-rated social adjustment (Linehan et al. 1993).
Schema Therapy (ST) is an integrative psychotherapy that combines elements of cognitive-behavioural, attachment, object relations, psychodynamic and emotionfocused models. ST was developed by Jeffrey Young for the treatment of people with chronic characterological problems and has been found to be an effective treatment for patients with BPD (Farrell et al. 2009; Giesen-Bloo et al. 2006; Nadort et al. 2009).

The construct of an early maladaptive schema (EMS) is central to ST. An EMS is defined as a broad, pervasive life theme or pattern comprised of memories, emotions and cognitions regarding oneself and one's relationship with others developed during childhood or adolescence and elaborated throughout one's lifetime and dysfunctional to a significant degree. Suicidal risk and behaviour could be conceptualized around the EMS and schema modes. Of the full range of 18 EMS which have been defined (Table 1), the ones (based on clinical observations) that are consistently associated with the most intense painful affect and greatest risk of suicidal behaviour are those involving disconnection and rejection (e.g. the emotional deprivation, social exclusion, mistrust/abuse, and abandonment schemas), especially when they have been developed early in childhood. This is clearly linked to the maternal deprivation animal model of suicide described in the previous section.

Suicidal behaviour, as distinct from risk, could conceptualize in terms of schema modes. There are four distinct types: child modes, maladaptive coping modes, maladaptive parent modes and a healthy adult mode (Table 2). The child modes (Vulnerable, Angry, Impulsive/Undisciplined, Contented) are ones that humans come into the world 
Table 2 Description of the schema modes of schema therapy [taken and adapted from Young et al. (2003)]

\section{Child modes}

Involve feeling, thinking and acting in a "childlike" manner

Vulnerable child (including abandoned, abused, humiliated, or lonely types) Feels overwhelmed by painful feelings, e.g. anxiety, depression, grief, shame/humiliation, or loneliness

Angry child Feels and expresses uncontrolled anger or rage in response to perceived or real mistreatment, abandonment, humiliation, or frustration; often feels treated unjustly. Acts like a child throwing a temper tantrum

Impulsive, undisciplined child "Wants what he wants when he wants it". Cannot tolerate the frustration of limits

\section{Maladaptive parent modes}

Involve internalized dysfunctional parent "voices"

Punitive/critical parent Internalized, critical or punishing parent voice; harsh criticism directed towards the self; feelings such as shame, guilt or self-loathing

Demanding parent Unrealistically high expectations; Pushy, controlling, demanding

\section{Maladaptive coping modes}

Involve maladaptive attempts to protect self from pain

\section{Avoidance modes}

Detached protector Emotional detachment used as protection from painful feelings; unaware of feelings; feels "nothing"; appears emotionally distant, flat, or robotic; avoids getting close to other people

Detached self-soother/self-stimulator Uses repetitive, "addictive", compulsive or self-stimulating behaviours to calm and soothe himself; uses pleasurable or exciting sensations to distance himself from painful feelings

Angry protector A "wall of anger" used to keep others at a safe distance; anger is more controlled than in Angry Child mode

Surrender mode

Compliant surrenderer Gives into real or perceived demands/expectations of others seen as more powerful in an anxious attempt to avoid pain/ get needs met

Over-compensator modes

Self-aggrandizer Feels superior, special or powerful; looks down on others; sees the world in terms of "top dog" and "bottom dog"; shows off or acts in a self-important, self-aggrandizing manner; concerned about appearances rather than feelings or real contact with others

Bully/attacker Uses threats, intimidation, aggression, coercion, retaliation to get what he wants; asserts his dominant position; feels sadistic pleasure in attacking others

Con man/manipulator Cons, lies or manipulates to achieve goals; victimizes others; seeks to escape punishment

Predator Focuses on eliminating threats, rivals, obstacles or enemies in a cold, ruthless and calculating manner

Over-controller (Paranoid and obsessive-compulsive) Focuses attention, ruminates and exercises extreme control in attempt to protect self from perceived or real threats paranoid types try to locate/uncover hidden threats; obsessive types use order, repetition, or ritual

\section{Healthy adult mode}

Serves as an "executive function" in which the healthy adult part nurtures and protects the vulnerable lonely child, sets limits for the angry child and battles or moderates the maladaptive coping modes so helping to meet the child's emotional needs

with and have close parallels to the child emotional systems that have been identified in mammalian brains (fear, panic, rage, seeking and play; Panskeep 1998). The Vulnerable Child mode, in the case of individuals who have suffered parental neglect and/or abuse, is characterized by an ongoing sense of deprivation and/or abuse and is labelled the Deprived/Abandoned or Abused Child mode. The Deprived/Abandoned/Abused Child mode is the one most commonly driving suicidal behaviour. Each mode is seen as having characteristic signs and symptoms, its own function and as requiring its own strategies to be effectively treated. The Deprived/Abandoned/Abused Child mode is characterized by neediness, frantic efforts to avoid abandonment, clinging, an idealized view of nurturers and feelings of depression, loneliness, hopelessness, despair, fear, panic, worthlessness and victimization. The individual feels helpless to get their needs met or find protection. One of the main strategies when this mode is activated and suicidal risk is high is to connect to, sooth, reassure and protect the "Vulnerable Child" part of the patient and provide enough ongoing contact (with the therapist or significant others) for the crisis to be weathered and core needs for connection to be met. This mode and these strategies have close parallels to the aforementioned animal models involving the central role of maternal deprivation in suicidal risk. Two other modes, the Detached Protector (one of the maladaptive coping modes) and the Punitive Parent (one of the maladaptive parent modes) are also involved with suicidal 
risk but involve a sense of self that other animals and even primates do not have. While these may be unique to Homo sapiens, the most important and central factor in the development and resolution of suicidal risk involves the Vulnerable Child mode; one we share with all other mammals.

All of the EMS (except for Entitlement/Grandiosity and Self-Sacrifice) have shown significant correlations with the temperament dimension "negative affectivity" and the trait "neuroticism" in child, adolescent and adult samples (Muris 2006; Thimm 2010; Rijkeboer and de Boo 2010). As mentioned above, consistent and strong correlations have been found between various measures of BPD and neuroticism. Consistent with this finding, it is observed clinically that when BPD patients fill out the Young Schema Questionnaire (Young 2005), a self-report inventory use to assess EMS, they almost always score highly on almost all 18 of the schemas making up the inventory.

Negative affectivity and anxiety proneness (precursors to neuroticism in adulthood) are associated with greater parental needs of the child (Van den Boom and Hocksma 1994). A prospective study that focused on the issue of how to best parent a needy child and that lends support to the plasticity hypothesis in relation to neuroticism and the s allele was conducted by Suomi (1997). The study investigated the developmental outcome of insufficient, normal and exceptionally good parenting of infant rhesus macaque monkeys with both normal and "neurotic" temperaments. One of the findings was that infant monkeys with normal temperament raised by inadequate parents (i.e. peers) developed behavioural and physiological characteristics of neurotic infants raised by normal parents. Infant monkeys with a neurotic temperament raised by normal mothers developed deficits in early exploration, exaggerated startle responses to minor stressors and a less secure attachment and were more likely to remain at the bottom of the dominance hierarchy. Interestingly, infant monkeys with a neurotic temperament raised by parents with exceptionally good parenting skills (i.e. being notably loving, nurturing and patient; qualities that are known to be essential for effective ST) expressed an even better developmental trajectory than infants with a normal temperament raised by normal parents. For example, they explored their environment more, displayed less behavioural disturbance during weaning, had an unusually secure attachment, rose to and maintained top positions in the dominance hierarchy and became highly nurturing parents themselves. The developmental trajectory of normal infants raised by exceptionally good parents was the same as that when raised by normal parents so the extra nurturance seemed to make no difference. Being a prospective study with primates, it allowed for control of all relevant variables throughout the period of investigation, making conclusions about causality more reliable than even the most tightly controlled prospective studies possible with humans. We therefore view this study as a striking example of the potential advantages of a responsive and affirmative stance towards the needs of patients with a temperament characterized by neuroticism, negative affectivity and increased risk of suicidal behaviour such as those diagnosed with BPD.

An outcome study in which ST was compared to transference focused therapy (TFP) in the treatment of BPD produced findings consistent with those discussed above (Giesen-Bloo et al. 2006). ST was found to be twice as effective as TFP and led to a significant reduction in all BPD manifestations and related psychopathology including suicidal risk and behaviour. ST also had a significantly lower dropout rate. It is worth noting that ST was still found to be twice as effective even when controlling for the lower dropout rate. This strengthens the greater impact of ST on suicidal behaviour and risk since it retained more patients who would otherwise be left at higher risk and more quickly and effectively reduced suicidal behaviour and other BPD symptomatology in the patients that remained in the study. The Schema Therapists in the study were selected and trained with a focus on being warm and highly nurturing in response to the BPD patient's intense affect and needs for soothing. This involved the therapists making direct contact with the patient's Vulnerable Child mode and providing emotional nutriments such as soothing, reassurance, validation, understanding and praise, along with empathic limits when needed. The experiences are seen as being internalized and thereby building the healthy adult part of the patient. TFP therapists, on the other hand, focused on the adult part of their patients, helping them gain a better insight into the nature of their needs and feelings and through this, learn how to better tolerate painful affect and self-sooth. A key difference between these two approaches, and between ST and almost all other therapies including DBT, is captured in this distinction between the internalization of "other-soothing" and training in "self-soothing". The former involves the assumption that the ability to self-sooth will grow spontaneously out of gratifying dependency needs. The latter involves a belief that directly gratifying patients' longings to be soothed and nurtured will do the opposite-impede and undermine the development of the capacity to self-sooth. Notably, the nurturing monkey parents were operating on the basis of internalization of other-soothing. We do not necessarily see this as a difference between good and bad. For children with less sensitive temperaments, there appears to be little difference between normal and exceptionally loving parenting and many young children and patients with either temperament can be trained to self-sooth. Moreover, a large percentage of the patients treated with TFP derived significant benefit. We believe, however, that providing training in self-soothing in response to these early core emotional 
needs could facilitate the development of compulsive selfreliance and risks promoting detachment from self and others as a means of coping with intense affect. This can result in individuals with more sensitive natures (e.g. s allele carries) not having full access to the nutriments that allow them to flourish. ST seems to be especially effective in its ability to capitalize on the plasticity associated with the $\mathrm{s}$ allele and more sensitive temperaments, including patients with BPD, and in so doing, to more effectively reduce or eliminate suicidal risk and behaviour.

The importance of "other-soothing" in relation to BPD is seen in the third significant correlation (in the negative direction) between this diagnosis and the Agreeableness scale of the NEO PI-r (Samual and Widiger 2008; Saulsman and Page 2004). This reflects the great difficulty of those diagnosed with BPD to trust and get along with others. The latter, in combination with the intense emotional suffering BPD patients endure, leaves them cut off from the soothing and responsiveness they need, thus falling back on compulsive self-reliance. The patients in the Giesen-Bloo et al. (2006) study attributed a large part of ST effectiveness to the extent the therapist actively reached out to form a connection with, and be responsive and soothing to, their vulnerable or "child side". This was also believed to be a major factor in the lower dropout rate.

The NEO PI-r Neuroticism, Conscientiousness and Agreeableness scales were all found to correlate with BPD. The combination of correlations on these three dimensions is unique to BPD. The strength of the correlation with neuroticism is also central. While, for example, APD also correlates significantly in a negative direction with Agreeableness and Conscientiousness, it correlates negatively rather than positively with neuroticism. The correlations found with BPD overlap well with the mode model that forms a central framework for the ST approach to this disorder. ST views BPD as made up of four distinct modes: the Vulnerable Child, Angry/Impulsive Child, Detached Protector and Punitive Parent modes. The Vulnerable Child mode is associated with reactions such as fear, anxiety, sadness, loneliness and hopelessness and thus has a clear link to neuroticism. The Angry/Impulsive Child mode corresponds with low Conscientiousness since the latter is associated with difficulties with restraint and impulse control. The Detached Protector mode is characterized by difficulty trusting others and a tendency towards interpersonal vigilance and keeping an emotional distance form oneself and others. This pattern is consistent with what is defined as low Agreeableness. The Punitive Parent mode (a critical/ punitive aspect of the self) generates feelings such as low self-esteem, self-loathing, shame and guilt and is clearly linked to neuroticism with a focus on the internal activity through which these feelings are generated. This overlap lends support to the mode model as a comprehensive framework with which to organize the key dimensions of a BPD patient's functioning and to its emphasis on the Vulnerable Child mode as the core of the treatment process. In addition to the "other-soothing" aspect of ST (a key element of a process called "limited reparenting"), the mode model was seen by the patients in the study as being one of the most helpful features of the treatment.

The results of this study were replicated by Nadort et al. (2009) in a second large-scale trial of ST in the treatment of BPD testing to see if ST could be successfully implemented in regular treatment settings. A randomized control trial of Group ST in comparison with treatment as usual in the treatment of BPD found Group ST to be significantly more effective and to have a significantly lower dropout rate (Farrell et al. 2009). The results of these studies were as strong as or stronger than the Giesen-Bloo et al. (2006) study suggesting that $\mathrm{ST}$ shows considerable promise as an approach to decrease the risk and incidence of suicidal behaviour.

Lending support to the hypothesized link between rhesus macaques, humans and neuroticism discussed above and for the previous discussion on animal models of suicide is that fact that animals, and especially primates such as rhesus macaques, exhibit individual differences in behaviour that mirror most of the major temperament dimensions in childhood and Big Five personality traits in adults (Weinstein et al. 2008). Only effortful control (Conscientiousness) is not widely evident in other species, although it can be observed in chimpanzees.

\section{Conclusions}

It has been argued that, from a neurobiological perspective, suicidal behaviour is related to functional abnormalities in specific brain regions that have been associated with a person's experience of the continuity of self, goal setting, decision making and emotion regulation. Biological suicide research has largely focused on low serotonin turnover. In current neurobiologically informed models, genetic predisposition and adverse childhood experiences (i.e. biological and psychosocial factors) are thought to interact during the developmental years, eventually resulting in the manifestation of neurobiological and clinical factors associated with suicidal behaviour. Clinically, these characteristics appear to be related to traits such as impulsivity and aggression, hopelessness and impaired problem-solving capacities.

Emerging studies on the nature of the genetic polymorphisms that underlie these abnormalities suggest that a paradigmatic shift is unfolding that sheds a new and brighter light on what has been viewed strictly in terms of the neurobiology of vulnerability. It appears that many of those who have less efficient serotonergic systems suffer 
the most and who are at the greatest risk of suicide suffer greatly in toxic and depriving environments and benefit the most from highly nurturing environments. These individuals may in fact have an especially strong capacity for deep and meaningful relationships, and ST seems to be especially well suited to capitalizing on these strengths, allowing these individuals to move beyond coping and reduced suicidal risk to living rich and deeply connected lives.

The developments in the field of neuroscience are now leading to a deeper and more precise understanding of how and why approaches such as ST are especially effective in the treatment of suicidal risk. The continuing integration of psychotherapeutic models with neurobiological concepts has the potential to help build on these early successes and to lead to the development of better therapies for suicidal individuals. It is conceivable that in the future, neuroimaging studies will help to identify which treatments are effective in increasing resilience to stressful experiences after one or several suicide attempts. Neurobiological perspectives of understanding are no contradiction to patient-oriented models of suicide.

\section{References}

Afifi TO, Boman J, Fleisher W, Sareen J (2009) The relationship between child abuse, parental divorce, and lifetime mental disorders and suicidality in a nationally representative adult sample. Child Abuse Negl 33:139-147

Agerbo E, Nordentoft M, Mortensen PB (2002) Familial, psychiatric, and socioeconomic risk factors for suicide in young people: nested case-control study. BMJ 13:325-374

Angst J, Angst F, Gerber-Werder R, Gamma A (2005) Suicide in 406 mood-disorder patients with and without long-term medication: a 40-44 years' follow-up. Arch Suicide Res 9:279-300

Antypa N, Van der Does W (2010) Serotonin transporter gene, childhood emotional abuse and cognitive vulnerability to depression. Genes Brain Behav 9:615-620

Arango V, Ernsberger P, Marzuk PM et al (1990) Autoradiographic demonstration of increased serotonin $5-\mathrm{HT}_{2}$ and beta-adrenergic receptor binding sites in the brain of suicide victims. Arch Gen Psychiatry 47:1038-1047

Arango V, Underwood M, Mann J (1992) Alterations in monoamine receptors in the brain of suicide victims. J Clin Psychopharm $12: 8 \mathrm{~S}-12 \mathrm{~S}$

Arango V, Underwood MD, Gubbi AV, Mann JJ (1995) Localized alterations in pre- and postsynaptic serotonin binding sites in the ventrolateral prefrontal cortex of suicide victims. Brain Res 688:121-133

Arias B, Collier DA, Gasto C, Pintor L, Gutierrez B, Valles V, Fananas L (2001) Genetic variation in the 5-HT5A receptor gene in patients with bipolar disorder and major depression. Neurosci Lett 303:111-114

Arora RC, Meltzer HY (1989) Serotonergic measures in the brains of suicide victims: 5- $\mathrm{HT}_{2}$ binding sites in the frontal cortex of suicide victims and control subjects. Am J Psychiatry 146:730-736

Asberg M (1997) Neurotransmitters and suicidal behavior. The evidence from cerebrospinal fluid studies. Ann N Y Acad Sci 836:158-181
Asberg M, Traskman L, Thoren P (1976) 5-HIAA in the cerebrospinal fluid. A biochemical suicide predictor? Arch Gen Psychiatry 33:1193-1197

Attar-Levy D, Martinot J-L, Blin J et al (1999) The cortical serotonin2 receptors studied with positron emission tomography and $\left[{ }^{18} \mathrm{~F}\right]$-setoperone during depressive illness and anti-depressant treatment with clomipramine. Biol Psychiatry 45:180-186

Audenaert K, Van Laere K, Dumont F et al (2001) Decreased frontal serotonin 5-HT 2a receptor binding index in deliberate selfharm patients. Eur J Nucl Med 28:175-182

Auerbach JG, Faroy M, Ebstein R, Kahana M, Levine J (2001) The association of the dopamine D4 receptor gene (DRD4) and the serotonin transporter promoter gene (5-HTTLPR) with temperament in 12-month-old infants. J Child Psychol Psychiatry 42:777-783

Banki CM, Arato M, Papp Z, Kurcz M (1984) Biochemical markers in suicidal patients. Investigations with cerebrospinal fluid amine metabolites and neuroendocrine tests. J Affect Disord 6:341-350

Barraclough B, Bunch J, Nelson B, Sainsbury P (1974) A hundred cases of suicide: clinical aspects. Br J Psychiatry 125:355-373

Bayle FJ, Leroy S, Gourion D, Millet B, Olié JP, Poirier MF, Krebs MO (2003) 5HTTLPR polymorphism in schizophrenic patients: further support for association with violent suicide attempts. Am J Med Genet B Neuropsychiatr Genet 119:13-17

Beck A, Steer R, Kovacs M, Garrison B (1985) Hopelessness and eventual suicide: a 10-year prospective study of patients hospitalized with suicidal ideation. Am J Psychiatry 142:559-563

Beck AT, Brown G, Steer RA (1989) Prediction of eventual suicide in psychiatric inpatients by clinical ratings of hopelessness. J Consult Clin Psychol 57:309-310

Bellivier F, Szöke A, Henry C, Lacoste J, Bottos C, Nosten-Bertrand M, Hardy P, Rouillon F, Launay JM, Laplanche JL, Leboyer M (2000) Possible association between serotonin transporter gene polymorphism and violent suicidal behavior in mood disorders. Biol Psychiatry 48:319-322

Belsky J, Pluess M (2009) Beyond diathesis stress: differential susceptibility to environmental influences. Psychol Bull 135:885-908

Berlie HD, Hurren KM (2013) Evaluation of lorcaserin for the treatment of obesity. Expert Opin Drug Metab Toxicol 9:1053-1059

Biver F, Wikler D, Lotstra F, Damhaut P, Goldman S, Mendlewicz J (1997) Serotonin 5-HT2 receptor imaging in major depression: focal changes in orbito-insular cortex. Br J Psychiatry 171:444-448

Bondy B, Erfurth A, de Jonge S, Kruger M, Meyer H (2000) Possible association of the short allele of the serotonin transporter promoter gene polymorphism (5-HTTLPR) with violent suicide. Mol Psychiatry 5:193-195

Bondy B, Buettner A, Zill P (2006) Genetics of suicide. Mol Psychiatry 11:336-351

Boothman L, Raley J, Denk F, Hirani E, Sharp T (2006) In vivo evidence that 5-HT(2C) receptors inhibit 5-HT neuronal activity via a GABAergic mechanism. Br J Pharmacol 149:861-869

Bortolato M, Pivac N, Muck Seler D, Nikolac Perkovic M, Pessia M, Di Giovanni G (2013) The role of the serotonergic system at the interface of aggression and suicide. Neuroscience 236:160-185

Boulougouris V, Chamberlain SR, Robbins TW (2009) Cross-species models of OC-spectrum disorders. Psychiatry Res 170:15-21

Bowlby J (1969) Attachment. Basic Books, New York

Brezo J, Paris J, Turecki G (2006) Personality traits as correlates of suicidal ideation, suicide attempts, and suicide completions: a systematic review. Acta Psychiatr Scand 113:180-206

Brodsky BS, Stanley B (2008) Adverse childhood experiences and suicidal behavior. Psychiatr Clin North Am 31:223-235 
Brodsky BS, Malone KM, Ellis SP, Dulit RA, Mann JJ (1997) Characteristics of borderline personality disorder associated with suicidal behavior. Am J Psychiatry 154:1715-1719

Brown GL, Goodwin FK (1986) Cerebrospinal fluid correlates of suicide attempts and aggression. Ann N Y Acad Sci 487:175-188

Bubar MJ, Cunningham KA (2008) Prospects for serotonin 5-HT $2 \mathrm{R}$ pharmacotherapy in psychostimulant abuse. Prog Brain Res 172:319-346

Canli T (2008) Toward a neurogenetic theory of neuroticism. Ann N Y Acad Sci 1129:153-174. doi:10.1196/annals.1417.022

Canli T, Lesch KP (2007) Long story short: the serotonin transporter in emotion regulation and social cognition. Nat Neurosci 10:1103-1109

Cannon B, Mulroy R, Otto MW, Rosenbaum JF, Fava M, Nierenberg AA (1999) Dysfunctional attitudes and poor problem solving skills predict hopelessness in major depression. J Affect Disord 55:45-49

Carlsson A, Svennerholm L, Winblad B (1980) Seasonal and circadian monoamine variations in human brains examined post mortem. Acta Psychiatr Scand Suppl 280:75-85

Caspi A, Sugden K, Moffitt TE, Taylor A, Craig IW, Harrington H, McClay J, Mill J, Martin J, Braithwaite A, Poulton R (2003) Influence of life stress on depression: moderation by a polymorphism in the 5-HTT gene. Science 301:386-389

Champoux M, Bennett A, Shannon C, Higley JD, Lesch KP, Suomi SJ (2002) Serotonin transporter gene polymorphism, differential early rearing, and behavior in rhesus monkey neonates. Mol Psychiatry 7:1058-1063

Charney DS, Woods SW, Goodman WK, Heninger GR (1987) Serotonin function in anxiety. II. Effects of the serotonin agonist MCPP in panic disorder patients and healthy subjects. Psychopharmacology 92:14-24

Cirulli F, Francia N, Brachi I, Antonucci M, Aloe L, Suomi SJ, Alleva E (2009) Changes in plasma levels of BDNF and NGF reveal a gender-selective vulnerability to early adversity in rhesus macaques. Psychoneuroendocrinology 34:172-180

Clayden RC, Zaruk A, Meyre D, Thabane L, Samaan Z (2012) The association of attempted suicide with genetic variants in the SLC6A4 and TPH genes depends on the definition of suicidal behavior: a systematic review and meta-analysis. Transl Psychiatry 2:e166

Coccaro EF, Siever LJ, Klar HM, Mauer G, Cochrane K, Cooper TB et al (1989) Serotonin studies in patients with affective and personality disorders. Arch Gen Psychiatry 46:587-599

Coccaro EF, Kavoussi RJ, Hauger RL (1995) Physiological responses to d-fenfluramine and ipsapirone challenge correlate with indices of aggression in males with personality disorder. Int Clin Psychopharmacol 10:177-179

Cole SW, Arevalo JM, Ruggiero AM, Heckman JJ, Suomi SJ (2012) Transcriptional modulation of the developing immune system by early life adversity. Proc Natl Acad Sci USA 109:20578-20583

Collado M, Serrano M (2010) Senescence in tumours: evidence from mice and humans. Nat Rev Cancer 10:51-57

Congdon E, Lesch KP, Canli T (2008) Analysis of DRD4 and DAT polymorphisms and behavioral inhibition in healthy adults: implications for impulsivity. Am J Med Genet B Neuropsychiatr Genet 147B:27-32

Costa PT Jr, McCrae RR (1995) Domains and facets: hierarchical personality assessment using the revised NEO personality inventory. J Pers Assess 64:21-50

Costanza A, D’Orta I, Perroud N, Burkhardt S, Malafosse A, Mangin P, La Harpe R (2013) Neurobiology of suicide: do biomarkers exist? Int J Legal Med. doi:10.1007/s00414-013-0835-6

Courtet P, Baud P, Abbar M, Boulenger JP, Castelnau D, Mouthon D, Malafosse A, Buresi C (2001) Association between violent suicidal behavior and the low activity allele of the serotonin transporter gene. Mol Psychiatry 6:338-341

Courtet P, Picot MC, Bellivier F, Torres S, Jollant F, Michelon C, Castelnau D, Astruc B, Buresi C, Malafosse A (2004) Serotonin transporter gene may be involved in short-term risk of subsequent suicide attempts. Biol Psychiatry 55:46-51

Crawley JN, Sutton ME, Pickar D (1985) Animal models of selfdestructive behavior and suicide. Psychiatr Clin North Am 8:299-310

Crişan L, Pană S, Vulturar R, Heilman RM, Szekely R, Drugă B, Dragod N, Miu AC (2009) Genetic contributions of the serotonin transporter to social learning of fear and economic decision making. Soc Cogn Affect Neurosci 4:399-408

De Luca V, Tharmaligam S, Strauss J, Kennedy JL (2008) 5-ht2c receptor and mao-a interaction analysis: no association with suicidal behaviour in bipolar patients. Eur Arch Psychiatry Clin Neurosci 258:428-433

Dekeyne A, Brocco M, Loiseau F, Gobert A, Rivet JM, Di Cara B, Cremers TI, Flik G, Fone KC, Watson DJ, Papp M, Sharp T, Serres F, Cespuglio R, Olivier B, Chan JS, Lavielle G, Millan MJ (2012) S32212, a novel serotonin type $2 \mathrm{C}$ receptor inverse agonist/alpha2-adrenoceptor antagonist and potential antidepressant: II. A behavioral, neurochemical, and electrophysiological characterization. J Pharmacol Exp Ther 340:765-780

Dettmer AM, Novak MA, Suomi SDJ, Meyer JS (2012) Physiological and behavioral adaptations to relocation stress in differentially reared rhesus monkeys: hair cortisol as a biomarker for anxietyrelated responses. Psychoneuroendocrinology 37:191-199

Dhaenen H, Bossuyt A, Mertens J, Bossuyt-Piron C, Gijesmans M, Kaufman L (1992) SPECT imaging of serotonin2 receptors in depression. Psychiatry Res Neuroimaging 45:227-237

Di Giovanni G, Di Matteo V, Di Mascio M, Esposito E (2000) Preferential modulation of mesolimbic vs. nigrostriatal dopaminergic function by serotonin $(2 \mathrm{C} / 2 \mathrm{~B})$ receptor agonists: a combined in vivo electrophysiological and microdialysis study. Synapse 35:53-61

Di Giovanni G, Di Matteo V, La Grutta V, Esposito E (2001) m-Chlorophenylpiperazine excites non-dopaminergic neurons in the rat substantia nigra and ventral tegmental area by activating serotonin-2C receptors. Neuroscience 103:111-116

Di Giovanni G, Di Matteo V, Pierucci M, Benigno A, Esposito E (2006) Central serotonin2C receptor: from physiology to pathology. Curr Top Med Chem 6:1909-1925

Di Giovanni G, Di Matteo V, Esposito E (eds) (2008) Serotonindopamine interaction: experimental evidence and therapeutic relevance. Elsevier, Amsterdam

Di Giovanni G, Esposito E, Di Matteo V (eds) (2011) 5-HT2C receptors in the pathophysiology of CNS disease. Springer, New York

Doudet D, Hommer D, Higley JD, Andreason PJ, Moneman R, Suomi SJ, Linnoila M (1995) Cerebral glucose metabolism, CSF 5-HIAA, and aggressive behavior in rhesus monkeys. Am J Psychiatry 152:1782-1787

Dracheva S, Chin B, Haroutunian V (2008) Altered serotonin 2C receptor RNA splicing in suicide: association with editing. NeuroReport 19:379-382

Dulchin MC, Oquendo MA, Malone KM, Ellis SP, Li S, Mann JJ (2001) Prolactin response to DL-fenfluramine challenge before and after treatment with paroxetine. Neuropsychopharmacology 25:395-401

Dumais A, Lesage AD, Alda M, Rouleau G, Dumont M, Chawky $\mathrm{N}$ et al (2005a) Risk factors for suicide completion in major depression: a case-control study of impulsive and aggressive behaviors in men. Am J Psychiatry 162:2116-2124

Dumais A, Lesage AD, Lalovic A et al (2005b) Is violent method of suicide a behavioral marker of lifetime aggression? Am J Psychiatry $162: 1375-1378$ 
Duval F, Mokrani MC, Correa H, Bailey P, Valdebenito M, Monreal J, Crocq MA, Macher JP (2001) Lack of effect of HPA axis hyperactivity on hormonal responses to D-fenfluramine in major depressed patients: implications for pathogenesis of suicidal behaviour. Psychoneuroendocrinology 26:521-537

Elliott R, Rubinsztein JS, Sahakian BJ, Dolan RJ (2002) The neural basis of mood-congruent processing biases in depression. Arch Gen Psychiatry 59:597-604

Evans E, Hawton K, Rodham K (2005) Suicidal phenomena and abuse in adolescents: a review of epidemiological studies. Child Abuse Negl 29:45-58

Fahlke C, Lorenz J, Long J, Champoux M, Suomi S, Higley J (2002) Rearing experiences and stress-induced plasma cortisol as early risk factors for excessive alcohol consumption in nonhuman primates. Alcohol Clin Exp Res 24:644-650

Farrell J, Shaw I, Webber M (2009) A schema-focused approach to group psychotherapy for outpatients with borderline personality disorder: a randomized controlled trial. J Behav Ther Exp Psychiatry 40:317-328

Fava M, Bless E, Otto M, Pava J, Rosenbaum J (1994) Dysfunctional attitudes in major depression changes with pharmacotherapy. $\mathrm{J}$ Nerv Ment Dis 182:45-49

Frankle WG, Lombardo I, New AS et al (2005) Brain serotonin transporter distribution in subjects with impulsive aggressivity: A positron emission study with [11C]McN 5652. Am J Psychiatry 162:915-923

Frokjaer VG, Mortensen EL, Nielsen FA et al (2008) Frontolimbic serotonin $2 \mathrm{~A}$ receptor binding in healthy subjects is associated with personality risk factors for affective disorder. Biol Psychiatry 63:569-576

Geyer MA, Markou A (1995) Animal models of psychiatric disorders. In: Bloom FE, Kupfer DJ (eds) Psychopharmacology: the fourth generation of progress. Raven Press, Ltd., New York, pp $787-798$

Ghaziuddin N, King CA, Welch KB, Zaccagnini J, Weidmer-Mikhail E, Mellow AM, Ghaziuddin M, Greden JF (2000) Serotonin dysregulation in adolescents with major depression: hormone response to meta-chlorophenylpiperazine (mCPP) infusion. Psychiatry Res 95:183-194

Giesen-Bloo J, van Dyck R, Spinhoven P, van Tilburg W, Carmen Dirksen C, van Asselt T, Kremers I, Nadort M, Arntz A (2006) Outpatient psychotherapy for borderline personality disorder: a randomized trial of schema focused therapy versus transference focused therapy. Arch Gen Psychiatry 63:649-658

Gonda X, Fountoulakis KN, Juhasz G, Rihmer Z, Lazary J, Laszik A, Akiskal HS, Bagdy G (2009) Association of the s allele of the 5-HTTLPR with neuroticism-related traits and temperaments in a psychiatrically healthy population. Eur Arch Psychiatry Clin Neurosci 259:106-113

Gonda X, Fountoulakis KN, Harro J, Pompili M, Akiskal HS, Bagdy G, Rihmer Z (2011) The possible contributory role of the S allele of 5-HTTLPR in the emergence of suicidality. J Psychopharmacol 25:857-866

Gonzalez A, Lovic V, Ward G, Wainwright P, Fleming A (2001) Intergenerational effects of complete maternal deprivation and replacement stimulation on maternal behavior and emotionality in female rats. Dev Psychobiol 38:11-32

Gottesman II, Gould TD (2003) The endophenotype concept in psychiatry: etymology and strategic intentions. Am J Psychiatry 160:636-645

Grant BF, Harford TC (1995) Comorbidity between DSM-IV alcohol use disorders and major depression: results of a national survey. Drug Alcohol Depend 39:197-206

Gunderson J, Lyons-Ruth K (2008) BPD's interpersonal hypersensitivity phenotype: a gene-environment-developmental model. J Pers Disord 22:22-41
Gurevich I, Tamir H, Arango V, Dwork AJ, Mann JJ, Schmauss C (2002) Altered editing of serotonin 2C receptor pre-mRNA in the prefrontal cortex of depressed suicide victims. Neuron 34:349-356

Hariri AR (2006) Genetically driven variation in serotonin function: impact on amygdale reactivity and individual differences in fearful and anxious personality. In: Canli T (ed) Biology of personality and individual differences. Guilford Press, New York, pp 295-316

Harvey ML, Swallows CL, Cooper MA (2012) A double dissociation in the effects of 5-HT2A and 5-HT2C receptors on the acquisition and expression of conditioned defeat in Syrian hamsters. Behav Neurosci 126:530-537

Hawton K, van Heeringen K (2009) Suicide. Lancet 373:1372-1381

Higley JD, Suomi SJ (2011) Impulsivity and aggression as personality traits in nonhuman primates. In: Weiss A, King J, Murray L (eds) Personality and temperament in nonhuman primates. Springer, New York, NY, pp 257-284

Higley JD, Hasert ML, Suomi SJ, Linnoila M (1991) A new nonhuman primate model of alcohol abuse: effects of early experience, personality, and stress on alcohol consumption. Proc Natl Acad Sci USA 88:7261-7265

Hitzemann R (2000) Animal models of psychiatric disorders and their relevance to alcoholism. Alcohol Res Health 24:149-158

Homberg JR, Lesch KP (2011) Looking on the bright side of serotonin transporter gene variation. Biol Psychiatry 69:513-519

Hoyer D, Pazos A, Probst A, Palacios JM (1986) Serotonin receptors in the human brain. II. Characterization and autoradiographic localization of 5- $\mathrm{HT}_{1 \mathrm{C}}$ and 5- $\mathrm{HT}_{2}$ recognition sites. Brain Res 376:97-107

Hrdina PD, Demeter E, Vu TB, Sotonyi P, Palkovits M (1993) 5-HT uptake sites and $5-\mathrm{HT}_{2}$ receptors in brain of antidepressant-free suicide victims/depressives: increase in $5-\mathrm{HT}_{2}$ sites in cortex and amygdala. Brain Res 614:37-44

Ichise M, Vines DC, Gura T, Anderson GM, Suomi SJ, Higley JD, Innis RB (2006) Effects of early life stress on [11C] DABS PET imaging of serotonin transporters in adolescent peer- and mother-reared rhesus monkeys. J Neurosci 26:4538-4543

Ingram RE, Luxton DD (2005) Vulnerability-stress models. In: Hankin BL, Abela JRZ (eds) Development of psychopathology: a vulnerability-stress perspective. Sage Publications, Thousand Oaks CA. Int Clin Psychopharmacol 10:177-179

Jacobs B, Driscoll L, Schall M (1997) Life-span dendritic and spine changes in areas 10 and 18 of human cortex: a quantitative Golgi study. J Comp Neurol 386:661-680

Jahn AL, Fox AS, Abercrombie HC, Shelton SE, Oakes TR, Davidson RJ, Kalin NH (2010) Subgenual prefrontal cortex activity predicts individual differences in hypothalamic-pituitary-adrenal activity across different contexts. Biol Psychiatry 67:175-181

Jakab R, Goldman-Rakic P (1998) 5-Hydroxytryptamine2A serotonin receptors in the primate cerebral cortex: possible site of action of hallucinogenic and antipsychotic drugs in pyramidal cell apical dendrites. Proc Natl Acad Sci USA 95:735-740

Kalbitzer J, Frokjaer VG, Erritzoe D et al (2009) The personality trait openness is related to cerebral 5-HTT levels. Neuroimage 45:280-285

Koch W, Schaaff N, Popperl G et al (2007) [I-123]ADAM and SPECT in patients with borderline personality disorder and healthy control subjects. J Psychiatry Neurosci 32:234-240

Kraemer GW, Clarke AS (1990) The behavioral neurobiology of selfinjurious behavior in rhesus monkeys. Prog Neuropsychopharmacol Biol Psychiatry 14:S141-S168

Kraemer G, Ebert M, Schmidt D, McKinney W (1991) Strangers in a strange land: a psychobiological study of infant monkeys before and after separation from real or inanimate mothers. Child Dev 62:548-566 
Krishnan V, Nestler EJ (2008) The molecular neurobiology of depression. Nature 455:894-902

Kuhn KU, Joe AY, Meyer K, Reichmann K, Maier W, Rao ML, Reinhardt MJ, Biersack HJ, Quednow BB (2004) Neuroimaging and 5-HT2C receptor polymorphism: a HMPAO-SPECT study in healthy male probands using mCPP-challenge of the 5-HT2C receptor. Pharmacopsychiatry 37:286-291

Lanzas C, Ayscue P, Ivanek R, Gröhn YT (2010) Model or meal? Farm animal populations as models for infectious diseases of humans. Nat Rev Microbiol 8:139-148

Lesch KP, Bengel D, Heils A et al (1996) Association of anxiety related traits with a polymorphism in the serotonin transporter gene regulatory region. Science 274:1527-1531

Lester D (1995) The concentration of neurotransmitter metabolites in the cerebrospinal fluid of suicidal individuals: a meta-analysis. Pharmacopsychiatry 28:45-50

Linehan MM, Armstrong HE, Suarez A, Allmon D, Heard HL (1991) Cognitive-behavioral treatment of chronically parasuicidal borderline patients. Arch Gen Psychiatry 48:1060-1064

Linehan MM, Heard HL, Armstrong HE (1993) Naturalistic followup of a behavioral treatment for chronically parasuicidal borderline patients. Arch Gen Psych 50:971-974

Liu S, Bubar MJ, Lanfranco MF, Hillman GR, Cunningham KA (2007) Serotonin2C receptor localization in GABA neurons of the rat medial prefrontal cortex: implications for understanding the neurobiology of addiction. Neuroscience 146:1677-1688

Lockwood G, Perris P (2012) A new look at core emotional needs. In: van Vreeswijk M, Broerson J, Nadort M (eds) The WileyBlackwell handbook of schema therapy: theory Research and Practice. Wiley-Blackwell, Malden, MA, pp 41-66

Lovic V, Gonzalez A, Fleming A (2001) Maternally separated rats show deficits in maternal care in adulthood. Dev Psychobiol 39:19-33

Lu W, Mueser KT, Rosenberg SD, Jankowski MK (2008) Correlates of adverse childhood experiences among adults with severe mood disorders. Psychiatr Serv 59:1018-1026

Malone KM, Corbitt EM, Li S, Mann JJ (1996) Prolactin response to fenfluramine and suicide attempt lethality in major depression. Br J Psychiatry 168:324-329

Mann JJ (1995) Violence and aggression. In: Bloom FE, Kupfer D (eds) Psychopharmacology: the fourth generation of progress. Raven Press, New York, pp 1919-1928

Mann J (1996) Postmortem studies of suicide victims. In: Watson S (ed) Biology of schizophrenia and affective disease. American Psychiatric Press Inc, London

Mann JJ (1998) The neurobiology of suicide. Nat Med 4:25-30

Mann JJ, Malone KM (1997) Cerebrospinal fluid amines and higherlethality suicide attempts in depressed inpatients. Biol Psychiatry 41:162-171

Mann JJ, Stanley M, McBride PA, McEwen BS (1986) Increased serotonin 2 and beta-adrenergic receptor binding in the frontal cortices of suicide victims. Arch Gen Psychiatry 43:954-959

Mann JJ, Oquendo M, Underwood MD, Arango V (1999) The neurobiology of suicide risk: a review for the clinician. J Clin Psychiatry 60(suppl 2):7-11 (discussion 18-20, 113-116)

Mann JJ, Huang YY, Underwood MD, Kassir SA, Oppenheim S, Kelly TM, Dwork AJ, Arango V (2000) A serotonin transporter gene promoter polymorphism (5-HTTLPR) and prefrontal cortical binding in major depression and suicide. Arch Gen Psychiatry $57: 729-738$

Martin CB, Ramond F, Farrington DT, Aguiar AS Jr, Chevarin C, Berthiau AS, Caussanel S, Lanfumey L, Herrick-Davis K, Hamon M, Madjar JJ, Mongeau R (2013) RNA splicing and editing modulation of 5-HT2C receptor function: relevance to anxiety and aggression in VGV mice. Mol Psychiatry $18: 656-665$
Matsumoto R, Ichise M, Ito H et al (2010) Reduced serotonin transporter binding in the insular cortex in patients with obsessivecompulsive disorder: a [11C]DASB PET study. Neuroimage 49:121-126

Matsunagaa M, Murakami H, Yamakawac K, Isowad T, Kasugaib K, Yonedab M, Kaneko H, Fukuyama S, Shinoda J, Yamada J, Ohira H (2010) Genetic variations in the serotonin transporter gene-linked polymorphic region influence attraction for a favourite person and the associated interactions between the central nervous and immune systems. Neurosci Lett 468:211-215

McBride PA, Brown RP, DeMeo M, Keilp J, Mieczkowski T, Mann JJ (1994) The relationship of platelet 5-HT2 receptor indices to major depressive disorder, personality traits, and suicidal behavior. Biol Psychiatry 35:295-308

McCann UD, Szabo Z, Seckin E et al (2005) Quantitative PET studies of the serotonin transporter in MDMA users and controls using $[11 \mathrm{C}] \mathrm{McN} 5652$ and [11C]DASB. Neuropsychopharmacology 30:1741-1750

McKinney WT (2001) Overview of the past contributions of animal models and their changing place in psychiatry. Semin Clin Neuropsychiatry 6:68-78

Meaney MJ (2001) Maternal care, gene expression, and the transmission of individual differences in stress reactivity across generations. Annu Rev Neurosci 24:1161-1192

Meltzer C, Price J, Mathis C et al (1999) PET imaging of serotonin type $2 \mathrm{~A}$ receptors in late-life neuropsychiatric disorders. Am J Psychiatry 156:1871-1878

Meyer J, Kapur S, Houle S et al (1999) Prefrontal cortex 5-HT 2 receptors in depression: a $\left[{ }^{18} \mathrm{~F}\right]$ setoperone PET imaging study. Am J Psychiatry 156:1029-1034

Meyer JH, Wilson AA, Ginovart N et al (2001) Occupancy of serotonin transporters by paroxetine and citalopram during treatment of depression: a [(11)C]DASB PET imaging study. Am J Psychiatry 158:1843-1849

Meyer JH, McMain S, Kennedy SH et al (2003) Dysfunctional attitudes and 5-HT(2) receptors during depression and self-harm. Am J Psychiatry 160:90-99

Meyer JH, Houle S, Sagrati S et al (2004) Brain serotonin transporter binding potential measured with carbon 11-labeled DASB positron emission tomography: effects of major depressive episodes and severity of dysfunctional attitudes. Arch Gen Psychiatry 61:1271-1279

Meyer JH, Wilson AA, Rusjan P et al (2008) Serotonin2A receptor binding potential in people with aggressive and violent behaviour. J Psychiatry Neurosci 33:499-508

Middeldorp CM, de Geus E, Willemsen G, Hottenga J, Slagboom P, Boomsmal D (2010) The serotonin transporter gene length polymorphism (5-HTTLPR) and life events: no evidence for an interaction effect on neuroticism and anxious depressive symptoms. Twin Res Hum Genet 13:544-549

Mintun MA, Sheline YI, Moerlein SM, Vlassenko AG, Huang Y, Snyder AZ (2004) Decreased hippocampal 5- $\mathrm{HT}_{2 \mathrm{~A}}$ receptor binding in major depressive disorder: in vivo measurement with $\left[{ }^{18} \mathrm{~F}\right]$ altanserin positron emission tomography. Biol Psychiatry 55:217-224

Mitterschiffthaler MT, Williams SC, Walsh ND et al (2008) Neural basis of the emotional Stroop interference effect in major depression. Psychol Med 38:247-256

Munafo MR, Clark TG, Flint J (2005) Promise and pitfalls in the meta-analysis of genetic association studies: a response to Sen and Shinka. Mol Psychiatry 10:895-897

Munafo MR, Freimer NB, Ng W, Ophoff R, Veijola J, Miettunen J, Jarvelin M-R, Taanila A, Flint J (2009) 5-HTTLPR genotype and anxiety-related personality traits: a meta-analysis and new data. Am J Med Genet B Neuropsychiatr Genet 150B:271-281 
Muris P (2006) Maladaptive schemas in non-clinical adolescents: relations to perceived parental rearing behaviours, big five personality factors, and psychopathological symptoms. Clin Psychol Psychother 13:405-413

Murphy DL, Lesch KP (2008) Targeting the murine serotonin transporter: insights into human neurobiology. Nat Rev Neurosci 9:85-96

Nadort M, Arntz A, Smit J, Giesen-Bloo J, Eikelenbooma M, Spinhoven P, van Asselt T, Wensing M, vanDyck R (2009) Implementation of out patient schema therapy for borderline personality disorder with versus without crisis support by the therapist outside office hours: a randomized trial. Behav Res Ther 47:961-973

Nelson EE, Herman KN, Barrett CE, Noble PL, Wojteczko K, Chisholm K, Delaney D, Ernst M, Fox NA, Suomi SJ, Winslow JT, Pine DS (2009) Adverse rearing experiences enhance responding to both aversive and rewarding stimuli in juvenile rhesus monkeys. Biol Psychiatry 66:702-704

Nestler EJ, Hyman SE (2010) Animal models of neuropsychiatric disorders. Nat Neurosci 13:1161-1169

Newport DJ, Stowe ZN, Nemeroff CB (2002) Parental depression: animal models of an adverse life event. Am J Psychiatry 159:1265-1283

Ni X, Chan K, Bulgin N, Sicard T, Bismil R, McMain S, Kennedy JL (2006) Association between serotonin transporter gene and borderline personality disorder. J Psychiatr Res 40:448-453

Norman W, Miller I, Dow M (1988) Characteristics of depressed patients with elevated levels of dysfunctional cognitions. Cog Ther Res 12:39-51

O'Regan D, Kwok RP, Yu PH, Bailey BA, Greenshaw AJ, Boulton AA (1987) A behavioural and neurochemical analysis of chronic and selective monoamine oxidase inhibition. Psychopharmacology 92:42-47

Oquendo MA, Mann JJ (2000) The biology of impulsivity and suicidality. Psychiatr Clin North Am 23:11-25

Oquendo MA, Galfalvy H, Russo S, Ellis SP, Grunebaum MF, Burke A, Mann JJ (2004) Prospective study of clinical predictors of suicidal acts after a major depressive episode in patients with major depressive disorder or bipolar disorder. A J Psychiatry 61:1433-1441

Panariello F, Javaid N, Luca V (2011) 5-HT2C receptors and suicidal behavior. In: Di Giovanni G, Esposito E, Di Matteo V (eds) 5-HT2C receptors in the pathophysiology of CNS disease, vol 22. Humana Press, New York, pp 261-274

Pandey GN (1997) Altered serotonin function in suicide. Evidence from platelet and neuroendocrine studies. Ann N Y Acad Sci 836:182-200

Pandey GN (2013) Biological basis of suicide and suicidal behavior. Bipolar Disord. doi:10.1111/bdi.12089

Pandey GN, Dwivedi Y, Rizavi HS et al (2002) Higher expression of serotonin 5-HT(2A) receptors in the postmortem brains of teenage suicide victims. Am J Psychiatry 159:419-429

Pandey GN, Dwivedi Y, Ren X, Rizavi HS, Faludi G, Sarosi A, Palkovits M (2006) Regional distribution and relative abundance of serotonin(2c) receptors in human brain: effect of suicide. Neurochem Res 31:167-176

Panskeep J (1998) Affective neuroscience: the foundations of human and animal emotions. Oxford University Press, New York

Placidi GP, Oquendo MA, Malone KM, Huang YY, Ellis SP, Mann JJ (2001) Aggressivity, suicide attempts, and depression: relationship to cerebrospinal fluid monoamine metabolite levels. Biol Psychiatry 50:783-791

Pluess M, Belsky J, Way B, Baldwin M, Taylor S (2010) 5-HTTLPR moderates effects of current life events on neuroticism: differential susceptibility to environmental influences. Prog Neuropsychopharmacol Biol Psychiatry 34:1070-1074
Pompili M, Girardi P, Ruberto A, Tatarelli R (2005) Suicide in borderline personality disorder: a meta-analysis. Nord J Psychiatry 59:319

Pooley EC, Houston K, Hawton K, Harrison PJ (2003) Deliberate self-harm is associated with allelic variation in the tryptophan hydroxylase gene (TPH A779C), but not with polymorphisms in five other serotonergic genes. Psychol Med 33:775-783

Praschak-Rieder N, Wilson AA, Hussey D et al (2005) Effects of tryptophan depletion on the serotonin transporter in healthy humans. Biol Psychiatry 58:825-830

Preti A (2007) Suicide among animals: a review of evidence. Psychol Rep 101:831-848

Preti A (2011) Animal model and neurobiology of suicide. Prog Neuropsychopharmacol Biol Psychiatry 35:818-830

Preti A, Miotto P (2005) Genetics, perinatal insult, and schizophrenia: the mechanism underlying an increased prevalence of perinatal complications among individuals with a diagnosis of schizophrenia? Curr Psychiatry Rev 1:139-150

Purselle DC, Nemeroff CB (2003) Serotonin transporter: a potential substrate in the biology of suicide. Neuropsychopharmacology 28:613-619

Qin P (2011) The impact of psychiatric illness on suicide: differences by diagnosis of disorders and by sex and age of subjects. J Psychiatr Res 45:1445-1452

Ramsden E, Wilson D (2010) The nature of suicide: science and the self-destructive animal. Endeavour 34:21-24

Reimold M, Smolka MN, Zimmer A et al (2007) Reduced availability of serotonin transporters in obsessive-compulsive disorder correlates with symptom severity-a [11C]DASB PET study. J Neural Transm 114:1603-1609

Rihmer Z (2007) Suicide risk in mood disorders. Curr Opin Psychiatry $20: 17-22$

Rijkeboer MM, de Boo GM (2010) Early maladaptive schemas in children: development and validation of the schema inventory for children. J Behav Ther Exp Psychiatry 41:102-109

Risch N, Herrell R, Liang KY, Lehner T, Eaves L, Hoh J, Griem A, Kovacs M, Ott J, Ries K, Merikangas KR (2009) Interaction between the serotonin transporter gene (5-HTTLPR), stressful life events, and risk of depression: a meta-analysis. JAMA 301:2462-2471

Robins E, Murphy G, Wilkinson R, Gassner S, Kayes J (1959) Some clinical considerations in the prevention of suicide based on a study of 134 successful suicides. Am J Public Health 49:888-899

Roggenbach J, Müller-Oerlinghausen B, Franke L (2002) Suicidality, impulsivity and aggression-is there a link to 5HIAA concentration in the cerebrospinal fluid? Psychiatry Res 113:193-206

Rosell DR, Thompson JL, Slifstein M et al (2010) Increased serotonin $2 \mathrm{~A}$ receptor availability in the orbitofrontal cortex of physically aggressive personality disordered patients. Biol Psychiatry 67:1154-1162

Rosenzweig-Lipson S, Sabb A, Stack G, Mitchell P, Lucki I, Malberg JE, Grauer S, Brennan J, Cryan JF, Sukoff Rizzo SJ, Dunlop J, Barrett JE, Marquis KL (2007) Antidepressant-like effects of the novel, selective, 5-HT2C receptor agonist WAY-163909 in rodents. Psychopharmacology 192:159-170

Roy A, Ågren H, Pickar D, Linnoila M, Doran A, Cutler N, Paul SM (1986) Reduced CSF concentrations of homovanillic acid and homovanillic acid to 5-hydroxyindoleacetic acid ratios in depressed patients: relationship to suicidal behavior and dexamethasone nonsuppression. Am J Psychiatry 143:1539-1545

Rush AJ, Beck AT, Kovacs M, Weissenburger J, Hollon SD (1982) Comparison of the effects of cognitive therapy and pharmacotherapy on hopelessness and self-concept. Am J Psychiatry 139:862-866

Ryding E, Ahnlide JA, Lindström M, Rosén I, Träskman-Bendz L (2006) Regional brain serotonin and dopamine transporter 
binding capacity in suicide attempters relate to impulsiveness and mental energy. Psychiatry Res 148:195-203

Salkovskis PM, Atha C, Storer D (1990) Cognitive-behavioural problem solving in the treatment of patients who repeatedly attempt suicide. A controlled trial. Br J Psychiatry 157:871-876

Samual DB, Widiger TA (2008) A meta-analytic review of the relationships between the five-factor model and DSM-IV-TR personality disorder: a facet level analysis. Clin Psychol Rev 28:1326-1342

Santana N, Bortolozzi A, Serrats J, Mengod G, Artigas F (2004) Expression of serotonin1A and serotonin2A receptors in pyramidal and GABAergic neurons of the rat prefrontal cortex. Cereb Cortex 14:1100-1109

Saulsman LM, Page AC (2004) The five-factor model and personality disorder empirical literature: a meta-analytic review. Clin Psychol Rev 23:1055-1085

Schinka JA, Buschand RM, Robichaux-Keene N (2004) A meta-analysis of the association between the serotonin transporter gene polymorphism (5-HTTLPR) and trait anxiety. Mol Psychiatry 9:197-202

Schmuck K, Ullmer C, Engels P, Lubbert H (1994) Cloning and functional characterization of the human $5-\mathrm{HT}_{2 \mathrm{~B}}$ serotonin receptor. FEBS Lett 342:85-90

Seligman ME (1972) Learned helplessness. Ann Rev Med 23:407-412

Selvaraj S, Hoshi R, Bhagwagar Z et al (2009) Brain serotonin transporter binding in former users of MDMA('ecstasy'). Br J Psychiatry 194:355-359

Sen SM, Burmeister D, Ghosh D (2004) Meta-analysis of the association between a serotonin transporter promoter polymorphism (5-HTTLPR) and anxiety-related personality traits. Am J Med Genet 127B:85-89

Serrats J, Mengod G, Cortes R (2005) Expression of serotonin 5-HT2C receptors in GABAergic cells of the anterior raphe nuclei. J Chem Neuroanat 29:83-91

Serretti A, Drago A, De Ronchi D (2007) HTR2A gene variants and psychiatric disorders: a review of current literature and selection of SNPs for future studies. Curr Med Chem 14:2053-2069

Serretti A, Calati R, Giegling I, Hartmann AM, Moller HJ, Rujescu D (2009) Serotonin receptor HTR1A and HTR2C variants and personality traits in suicide attempters and controls. J Psychiatr Res 43:519-525

Shannon C, Schwandt ML, Champoux M, Shoaf SE, Suomi SJ, Linnoila M, Higley JD (2005) Maternal absence and stability of individual differences in CSF 5-HIAA concentrations in rhesus monkey infants. Am J Psychiatry 162:1658-1664

Sharot T, Riccardi AM, Raio CM, Phelps EA (2007) Neural mechanisms mediating optimism bias. Nature 450:102-105

Simons AD, Murphy GE, Levine JL, Wetzel RD (1986) Cognitive therapy and pharmacotherapy for depression. Sustained improvement over one year. Arch Gen Psychiatry 43:43-48

Soloff PH, Price JC, Meltzer CC, Fabio A, Frank GK, Kaye WH (2007) $5 \mathrm{HT}_{2 \mathrm{~A}}$ receptor binding is increased in borderline personality disorder. Biol Psychiatry 62:580-587

Spinelli S, Chefer S, Suomi SJ, Barr CS, Stein E (2009) Early-life stress induces long-term morphological changes in primate brain. Arch Gen Psychiatry 66:658-665

Stanley M, Traskman-Bendz L, Dorovini-Zis K (1985) Correlations between aminergic metabolites simultaneously obtained from human CSF and brain. Life Sci 37:1279-1286

Stanley B, Molcho A, Stanley M, Winchel R, Gameroff MJ, Parsons B, Mann JJ (2000) Association of aggressive behavior with altered serotonergic function in patients who are not suicidal. Am J Psychiatry 157:609-614

Stefulj J, Buttner A, Skavic J, Zill P, Balija M, Eisenmenger W, Bondy B, Jernej B (2004) Serotonin 1B (5HT-1B) receptor polymorphism (G861C) in suicide victims: association studies in German and Slavic population. Am J Med Genet B Neuropsychiatr Genet 127B:48-50

Stein MB, Schork NJ, Gelernter J (2008) Gene-by-environment (serotonin transporter and childhood maltreatment) interaction for anxiety sensitivity, an intermediate phenotype for anxiety disorders. Neuropsychopharmacology 33:312-319

Stockmeier CA (2003) Involvement of serotonin in depression: evidence from postmortem and imaging studies of serotonin receptors and the serotonin transporter. J Psychiatr Res 37:357-373

Stockmeier CA, Dilley GE, Shapiro LA, Overholser JC, Thompson PA, Meltzer HY (1997) Serotonin receptors in suicide victims with major depression. Neuropsychopharmacology 16:162-173

Suhara T, Takano A, Sudo Y et al (2003) High levels of serotonin transporter occupancy with low-dose clomipramine in comparative occupancy study with fluvoxamine using positron emission tomography. Arch Gen Psychiatry 60:386-391

Suomi SJ (1997) Early determinants of behaviour: evidence from primate studies. Br Med Bull 53:170-184

Suomi SJ (2011) Risk, resilience, and gene-environment interplay in primates. J Can Acad Child Adolesc Psychiatry 20:289-297

Suominen K, Isometsa E, Suokas J, Haukka J, Achte K, Lonnqvist J (2004) Completed suicide after a suicide attempt: a 37-year follow-up study. Am J Psychiatry 161:562-563

Taylor SE, Way BM, Welch WT, Hilmert CJ, Lehman BJ, Eisenberger NI (2006) Early family environment, current adversity, the serotonin transporter promoter polymorphism, and depressive symptomatology. Biol Psychiatry 60:671-676

Takano A, Arakawa R, Hayashi M, Takahashi H, Ito H, Suhara T (2007) Relationship between neuroticism personality trait and serotonin transporter binding. Biol Psychiatry 62:588-592

Terracciano A, Balaci L, Thayer J, Scally M, Kokinos S, Ferrucci L (2009) Variants of the serotonin transporter gene and NEO-PI-R Neuroticism: no association in the BLSA and SardiNIA samples. Am J Med Genet B Neuropsychiatr Genet 150B:1070-1077

Thimm JC (2010) Personality and early maladaptive schemas: a five-factor model perspective. J Behav Ther Exp Psychiatry 41:373-380

Tiefenbacher S, Novak MA, Lutz CK, Meyer JS (2005) The physiology and neurochemistry of self-injurious behavior: a nonhuman primate model. Front Biosci 10:1-11

Todd KG, McManus DJ, Baker GB (1995) Chronic administration of the antidepressants phenelzine, desipramine, clomipramine, or maprotiline decreases binding to 5-hydroxytryptamine2A receptors without affecting benzodiazepine binding sites in rat brain. Cell Mol Neurobiol 15:361-370

Tondo L, Lepri B, Baldessarini RJ (2008) Suicidal status during antidepressant treatment in 789 Sardinian patients with major affective disorder. Acta Psychiatr Scand 118:106-115

Träskman L, Åsberg M, Bertilsson L, Sjöstrand L (1981) Monoamine metabolites in CSF and suicidal behavior. Arch Gen Psychiatry 38:631-636

Turecki G, Briere R, Dewar K et al (1999) Prediction of level of serotonin $2 \mathrm{~A}$ receptor binding by serotonin receptor $2 \mathrm{~A}$ genetic variation in postmortem brain samples from subjects who did or did not commit suicide. Am J Psychiatry 156:1456-1458

Turecki G, Sequeira A, Gingras Y, Seguin M, Lesage A, Tousignant M, Chawky N, Vanier C, Lipp O, Benkelfat C, Rouleau GA (2003) Suicide and serotonin: study of variation at seven serotonin receptor genes in suicide completers. Am J Med Genet B Neuropsychiatr Genet 118B:36-40

Turecki G, Ernst C, Jollant F, Labonté B, Mechawar N (2012) The neurodevelopmental origins of suicidal behavior. Trends Neurosci 35:14-23

Uher R, McGuffin P (2009) The moderation by the serotonin transporter gene of environmental adversity in the etiology of depression: update. Mol Psychiatry 1:18-22 
van den Boom DC, Hocksma JB (1994) The effect of infant irritability on mother-infant interaction: a growth curve analysis. Dev Psychol 30:581-590

van Heeringen C, Audenaert K, Van Laere K et al (2003) Prefrontal $5-\mathrm{HT}_{2 \mathrm{a}}$ receptor binding index, hopelessness and personality characteristics in attempted suicide. J Affect Disord 74:149-158

Videtic A, Zupanc T, Pregelj P, Balazic J, Tomori M, Komel R (2009) Suicide, stress and serotonin receptor $1 \mathrm{~A}$ promoter polymorphism -1019C > G in Slovenian suicide victims. Eur Arch Psychiatry Clin Neurosci 259:234-238

Walker C, Scribner K, Cascio C, Dallman M (1991) The pituitary adrenocortical system of neonatal rats is responsive to stress throughout development in a time-dependent and stressor specific fashion. Endocrinology 128:1385-1395

Way BM, Taylor SE (2010) The serotonin transporter promoter polymorphism is associated with cortisol response to psychosocial stress. Biol Psychiatry 67:487-492

Weinstein T, Capitanio JP, Gosling SD (2008) Personality in animals. In: John OP, Robins RW, Pervin LA (eds) Handbook of personality, 3rd edn. Guilford Press, New York, pp 328-348

Weiss D, Coccaro EF (1997) Neuroendocrine challenge studies of suicidal behavior. Psychiatr Clin North Am 20:563-579
Willis-Owen AG, Turri MG, Munafò MR, Surtees PG, Wainwright N, Brixey RD, Flint J (2005) The Serotonin transporter length polymorphism, neuroticism, and depression: a comprehensive assessment of association. Biol Psychiatry 58:451-456

Yates M, Leake A, Candy JM, Fairbairn AF, McKeith IG, Ferrier IN (1990) $5 \mathrm{HT}_{2}$ receptor changes in major depression. Biol Psychiatry 27:489-496

Young JE (2005) Young schema questionnaire: long form, version 3. Schema Therapy Institute, New York

Young JE, Klosko JS, Weishaar ME (2003) Schema therapy: a practitioner's guide. Guilford Press, NY

Young K, Holcomb L, Bonkale W, Hicks P, Yazdani U, German D (2007) 5HTTLPR polymorphism and enlargement of the pulvinar: unlocking the backdoor to the limbic system. Biol Psychiatry 61:813-818

Zhang J, Shen Y, He G, Li X, Meng J, Guo S, Li H, Gu N, Feng G, He L (2008) Lack of association between three serotonin genes and suicidal behavior in Chinese psychiatric patients. Prog Neuropsychopharmacol Biol Psychiatry 32:467-471 